\title{
Adventures in Higher Education, Happiness, AND MindFulness
}

\author{
Peter H. Huang*
}

\begin{abstract}
This Article recounts my unique adventures in higher education, including being a Princeton University freshman mathematics major at age 14, Harvard University applied mathematics graduate student at age 17, economics and finance faculty at multiple schools, first-year law student at the University of Chicago, second-and third-year law student at Stanford University, and law faculty at multiple schools. This Article also candidly discusses my experiences as student and professor and openly shares how I achieved sustainable happiness by practicing mindfulness to reduce fears, rumination, and worry in facing adversity, disappointment, and setbacks. This Article analyzes why law schools should teach law students about happiness and mindfulness. This Article discusses how to teach law students about happiness and mindfulness. Finally, this Article provides brief concluding thoughts about how law students can sustain happiness and mindfulness once they graduate from law school.
\end{abstract}

\section{KEYWORDS}

Happiness, Mindfulness, Wellness, Higher Education, Legal Education

\section{CONTENTS}

INTRODUCTION 427

I. My Unique Adventures in Higher Education 432

A. Princeton University Freshman at the Age of 14 ..... 432

B. Harvard University Graduate Student at the Age of 17 440

* Professor and DeMuth Chair of Business Law, University of Colorado Law School. Visiting Scholar, Loyola Los Angeles Law School. J.D., Stanford Law School; Ph.D., Harvard University; A.B., Princeton University. I dedicate this Article to my beloved Aunt Margaret Soong Meow Lee, a bilingual educator who exemplified happiness through mindfulness, and who passed away way too soon. Thanks for helpful conversations, discussions, insights, and suggestions to Jim Anaya, Debra S. Austin, Anne M. Brafford, Jim Chen, Rebecca Huss, Martha Knudson, Kate Mayer Mangan, and Len Riskin, students I have taught, the audience of a session at the 2017 University of Colorado law school faculty scholarship retreat Making a Difference: Impactful Legal Scholarship, participants from the University of Colorado law school summer 2017 conference Positive Lawyering, Mindfulness, and Humane Games, the audience of the panel Ethical Curricula at the 24th International Learner conference, the audience of a Southwestern law school visiting speaker series presentation, especially those at a fun lunch afterwards, and those from the 2020 class of the University of Colorado law school who shared feedback and thoughts about my presentation about mindfulness at their orientation. 
C. Economics or Finance Faculty at Multiple Schools.......................448

D. Stanford University 2L-3L and University of Chicago 1L .........451

E. Law Faculty at Multiple Schools ...................................................453

II. Why Teach Law Students About Happiness and Mindfulness? 456

A. Law Student Discontent, Unhappiness, and Suffering. 457

B. What Motivates Law School Applicants, Students, and Alumni?461

C. What Motivates Clients of Law School Graduates? 466

D. Unhappy Law Students Become Unhappy Lawyers .467

E. What Motivates Law Professors?

III. Ways to Teach Law Students About Happiness and Mindfulness 471

A. Resources to Teach Law Students About Happiness and Mindfulness

B. My Experiences in Teaching Happiness and Mindfulness to Law Students. 481

IV. Conclusions. .483 


\section{INTRODUCTION}

My life-long curiosity, interest, and passion about education, higher education, learning, and teaching started at a young age when my tiger mom ${ }^{1}$ purchased for me a set of Ivy League book covers when I was six years old in the first grade at Public School (P.S.) 183 and explained that there are eight schools in the Ivy League: Harvard, Yale, Princeton, and five other places. ${ }^{2}$ Five years later, when I was in sixth grade at P.S. 183, my mom called to ask about the admissions process to Brearley, ${ }^{3}$ an independent school on the upper east side of Manhattan. When a Brearley admissions office employee told my mom that her son could not go to Brearley, my mom asked why not and was it because her son is an American born Chinese? The Brearley admissions office employee replied that it was because Brearley was and still is an all girl's K-12 school.

Two years later, while attending Horace Mann, ${ }^{4}$ an independent country day college preparatory school in Riverdale, a neighborhood of the Bronx, New York, I developed a crush on my eighth-grade algebra teacher, a recent graduate of Columbia University Teacher's College. I would write her love poems in German (because I was taking German) and signed my quizzes "Mit Liebe," ("With Love"). For Valentine's day, I gave her an equation in polar coordinates that depicts a rotated cardiod, namely $\mathrm{r}(\mathrm{q})=1-\sin (\mathrm{q}) .^{5}$

Because my mom was worried that her number one son would be distracted from studying by my harmless crush, my mom took me to see the chair of the New York University (NYU) mathematics department at the Courant Institute of Mathematical Sciences. We convinced him to let me audit pre-calculus and calculus I in between my eighth and ninth grades, during the six-week first session of NYU summer school. I sat front and center in the first row every day, did all the assigned and extra credit homework, and took the in-class final examinations in both courses. Both professors wrote letters to whom it may concern stating that I would have earned a course grade of A had I been enrolled in the courses. I was allowed that July and August to enroll for credit at NYU in calculus II during the six-week second session of summer school and earned a course grade of A. I returned to start ninth grade at Horace Mann without any further mathematics to take (mission accomplished mom). I believed the Chinese concept qi (chi) of a life force was similar to gravity, electricity, and magnetism in the sense there are (differential) equations that describe how and why acupuncture works. I found it fun and helpful to apply calculus in understanding practically every aspect of life, ${ }^{6}$

Peter H. Huang, Tiger Cub Strikes Back: Memoirs of an Ex-Child Prodigy About Legal Education and Parenting, 1 BRit. J. Am. Legal Stud. 297, 297, 300 (2012).

2 Peter H. Huang, Meta-Mindfulness: A New Hope, 19 Richmond J.L. \& Pub. Int. 303, 308 (2016).

3 Brearley Website, https://www.brearley.org/page.

4 Horace Mann School, http://www.horacemann.org/.

5 See, e.g., Wolfram MathWorld, Heart Curve, http://mathworld.wolfram.com/ HeartCurve.html.

6 Oscar E. Fernandez, Everyday Calculus: Discovering the Hidden Math All AROUND Us (2017). 
including biology, economics, and social interaction. ${ }^{7}$ I delighted in learning how to apply calculus to solve problems in physics. For some reason, I took eleventh grade physics (non-AP, which meant no calculus in the course) instead of ninth grade biology and skipped tenth grade chemistry.

I applied at the age of 13 during the fall of ninth grade to attend these colleges the following academic year: Harvard, Yale, Princeton, Columbia, and NYU. ${ }^{8}$ I did not graduate from Horace Mann because New York state law requires taking health and sex education to graduate and one had to be at least age 16 to take health and sex. I thus left Horace Mann without a high school diploma. Because I never took a General Educational Development (GED) test, ${ }^{9}$ I am a high school dropout without any high school equivalency credential. This means that, unlike the character Maverick Tom Cruise played in Top Gun, ${ }^{10} \mathrm{I}$ cannot attend truck driving school, which requires a high school diploma or its equivalent.

I have always been fascinated by how and why some people learn the same material or skill better, easier, and quicker than others. People's heterogeneity in learning costs, effectiveness, efficiency, and speed presumably result in part from differences in ability, attention, discipline, effort, environment, genetics, identity, mindset, motivation, resilience, and time. Education professor $\mathrm{Jin} \mathrm{Li}$ analyzes fundamental differences in the cultural orientations that exist between EuropeanAmerican and East Asian attitudes towards learning, despite both cultures having similar educational content in their K-12 systems and valuing the goal of learning. ${ }^{11}$ In a European-American model of learning stemming from a Western intellectual tradition of Socrates, the goal of education is to cultivate the mind to expand the depth of knowledge about our world. European-American learning focuses on developing these four essential pursuits: active engagement, critical thinking, exploration, and self-expression. In an East Asian model of learning arising from an Eastern intellectual tradition of Confucius, education focuses on developing ethical character and personal excellence. East Asian learning centers on five key virtues aimed at perfecting the moral self: concentration, diligence, endurance, perseverance, and sincerity.

These different models of learning inform the mindsets of students and teachers. These different views about learning also influence and permeate different associated cultural notions of education and parenting. There are cost and benefits to any (education and) parenting style, including tiger parenting. ${ }^{12} \mathrm{I}$ have written elsewhere at some length about how American legal education and tiger parenting share much in common. ${ }^{13}$ A law professor recently wrote about how helicopter

7 Oscar E. Fernandez, The Calculus of Happiness: How a Mathematical Approach to Life Adds up to Health, Wealth, And Love (2017).

8 In case the reader is curious, I was accepted by Princeton, Columbia, and NYU, rejected by Yale, and asked by Harvard to withdraw my application and reapply in three years. I would have been able to finish college in two years at NYU with $100 \%$ faculty dependent tuition remission. I would have been able to live at home attending Columbia. Princeton was the choice because it was the highest ranked of the accepted set and known for its world class mathematics department.

9 GED Testing Service, https://www.gedtestingservice.com/educators/home.

10 Top Gun (Paramount Pictures 1986).

11 Jin Li, Cultural Foundations of Learning: East and West (2012).

12 Huang, supra note 1 , at 309.

13 Huang, supra note 1, at 297, 300-01. 
(law) professors may, like helicopter parents, end up harming pedagogically and professionally their (law) students..$^{14}$

Evaluating different ways of teaching (and parenting) presupposes a normative criterion or criteria by which to measure flourishing, progress, or success. ${ }^{15}$ Happiness or subjective well-being provides one such natural metric. ${ }^{16}$ Martin Seligman, a founder of the field of positive psychology, ${ }^{17}$ suggested these five components of happiness and well-being summarized by the mnemonic acronym PERMA: Positive emotion, Engagement, Relationships, Meaning, and Accomplishment. ${ }^{18}$ How do law students and lawyers fare in terms of PERMA? The good news is that a majority of law students and lawyers do not have a mental health or substance use disorder. ${ }^{19}$ The bad news is that this does not mean the majority of law students and lawyers are flourishing. Many law students and lawyers report experiencing anxiety, ${ }^{20}$ depression, ${ }^{21}$ and chronic stress. ${ }^{22}$ Unfortunately, many law students also report engaging in high levels of substance abuse to cope with anxiety and depression, ${ }^{23}$ while few sought help for mental health issues or alcohol and drug

14 Emily Grant, Helicopter Professors, Jan. 23, 2017, https://papers.ssrn.com/sol3/papers. cfm?abstract_id=2904752. See also Paul Caron, Helicopter Professors Are Hurting Their Students, TAx Prof Blog, Jan. 30, 2017, http://taxprof.typepad.com/taxprof blog/2017/01/helicopter-law-professors-are-hurting-their-students.html; Steven Cohn, The Rise of the Helicopter Teacher, The Conversation, THe Chronicle of Higher Education, Aug.5, 2014, http://www.chronicle.com/blogs/conversation/2014/08/05/ the-rise-of-the-helicopter-teacher/; Berlin Fang, How to Avoid Being a Helicopter Professor, FACULTY Focus, June 8, 2015, https://www.facultyfocus.com/articles/ teaching-careers/how-to-avoid-being-a-helicopter-professor/. But see Barry Thomas, Helicopter Professor and Proud!, The Evollution, Aug. 2, 2016, https://evollution. $\mathrm{com} /$ programming/teaching-and-learning/helicopter-professor-and-proud/.

15 Huang, supra note 1 , at 303.

16 Id. at 303-04.

17 See generally Martin E.P. Seligman, Authentic Happiness: Using the New Positive Psychology to Realize Your Potential for Lasting Fulfillment (2004).

18 See generally Martin E.P. Seligman, Flourish: A Visionary New Understanding of HAPPINESS AND WELL-BEING (2012).

19 National Task Force on Lawyer Well-Being, The Path to Lawyer Well-Being: Practical Recommendations for Positive Change, Aug. 14, 2017, https://www.americanbar.org/content/dam/aba/images/abanews/ ThePathToLawyerWellBeingReportFINAL.pdf.

20 Jeena Cho, Talking About the Elephant in the Room - Social Anxiety, ABA J., Aug. 9, 2017, 8:30 am, CDT, http://www.abajournal.com/news/article/talking_about_the_ elephant_in_the_room_social_anxiety; JEENA Cho \& KAREN GILFORD, THE ANXIOUS Lawyer: AN 8-Week Guide to a Joyful and Satisfying Law Practice Through Mindfulness and Meditation (2016); Annie Little, Anxiety, Law + Me (It's Not Just You), JD NATION, http://www.thejdnation.com/anxiety-law-me-its-not-just-you/.

21 Joe Patrice, If You're In Law School, You're Probably Depressed, Jan. 15, 2015 at 2:57 PM, Авоve тHE LAW, http://abovethelaw.com/2015/01/if-youre-in-law-school-youreprobably-depressed/.

22 Barbara Glesner Fines, Law School and Stress, LawLifeline, http://www.lawlifeline. org/articles/458-law-school-and-stress.

23 Jerome M. Organ, David B. Jaffee, \& Katherine M. Bender, Suffering in Silence: The Survey of Law Student Well-Being and the Reluctance of Law Students to Seek Help for Substance Use and Mental Health Concerns, 66 J. Legal Educ. Autumn 2016, at 116, 127-38. 
abuse, with many expressing concern over seeking help being a potential threat to bar admission or employment. ${ }^{24}$ Unhappy, unhealthy law students graduate to become zombie lawyers. ${ }^{25}$ Many lawyers report a "profound ambivalence" over the work they do to make a living. ${ }^{26}$

Patrick Krill, an attorney, board certified alcohol and drug counselor, expert on lawyers' addiction and mental health issues, and lead author of the first and only national study of lawyer mental health problems and substance abuse, ${ }^{27}$ recently wrote in the preface to an autobiography about an addicted lawyer: ${ }^{28}$

\begin{abstract}
In addition to the eye-popping rates of problem drinking and depression, the research demonstrated that the problems are widespread and systemic, affecting all practice settings, all age groups, all experience levels, and all work environments, from the most rural to the most urban . . . very high rates of alcohol use disorders, depression, anxiety, and stress are plaguing attorneys across the country, in all stages of their careers, and in every practice setting. Younger lawyers newer to the profession are the ones experiencing the highest rates of problem drinking and other mental health concerns. ${ }^{29}$
\end{abstract}

I and many people I know struggled with anxiety, depression, and chronic stress in law school and law practice. It is natural that all of us will feel down, lost, and overwhelmed at various points in our personal and professional lives. Law students and lawyers often are overly critical of others and themselves. Practicing mindfulness provides a helpful sense of perspective, compassion, and selfcompassion. I still vividly remember feeling anxious, depressed, and chronically stressed at various times as a child, adolescent, 1L, and law professor.

A large and still growing body of neuroscience and psychology research empirically shows that practicing mindfulness can help manage anxiety, depression, and chronic stress. ${ }^{30}$ Law professor Katrina Lee proposed that law schools link mindfulness with legal technology courses to reduce law student stress, increase creativity, and decrease bias. ${ }^{31}$ My maternal grandmother introduced me as a child to practicing mindfulness, ${ }^{32}$ through her example of a

\title{
Id. at $140-42$.
}

25 Peter H. Huang \& Corie Rosen Felder, The Zombie Lawyer Apocalypse, 42 PePP. L. Rev. 727 (2015).

26 David L. Chambers, Overstating the Satisfaction of Lawyers, 39 LaW \& Soc. INQUIRY 1 (2014).

27 Patrick Krill, Ryan Johnson, \& Linda Albert, The Prevalence of Substance Use and Other Mental Health Concerns Among American Attorneys, 10 J. AdDiction Med. 46 (2016).

28 Brian Cuban, The Addicted lawyer: Tales of the Bar, Booze, Blow, and REDEMPTION (2017).

29 Id. at viii-ix.

30 See, e.g., Mindfulness Goes Mainstream (PBS broadcast Aug. 2017), http://pressroom. pbs.org/Programs/m/MindFulness-Goes-MainstREAM.

31 Katrina Lee, A Call for Law Schools to Link the Curricular Trends of Legal Tech and Mindfulness, 48 TOLEDo L. Rev. 55 (2016).

32 Huang, supra note 2, at 315. 
daily meditative practice with a set of mala beads..$^{33}$ Developing and sustaining a mindfulness practice has helped me cope with and manage anxiety, depression, and chronic stress. It is not even a slight exaggeration to say that mindfulness has saved my life and helped me to achieve and sustain calmness, confidence, happiness, meaning, and peace.

Some law professors and law students believe the anxiety, stress, suffering, and unhappiness that many law students experience in law school forges them into tougher individuals and will make them become more effective future advocates. Some law professors and law students believe the negative aspects of law school experience are similar to fraternity or military hazing in being able to build character and resilience. Unfortunately, the belief "that depression among lawyers is inevitable or even desirable is not only incorrect, it also encourages the legal academy to do nothing to mitigate the psychological trouble that many law students experience." ${ }^{34}$

Other law professors and law students are enamored with the myths of lawyer, law student, and law school essentialism and exceptionalism. A cynical or University of Chicago economically-minded person may argue that for lawyers and law students to stay in law practice and law school with that much anxiety, depression, and chronic stress, there has to be compensating benefits, such as higher than competitive (at least expected) salaries, perks, and returns. There are several responses, including there is a mass exodus from law practice, especially of women and minorities, ${ }^{35}$ people are heterogeneous in their threshold for pain and suffering, and the power of inertia.

Additionally, some law students and lawyers become addicted to the drama, stress, and pain of law school and law practice in the same way that some people become addicted to the drama, stress, and pain of a dysfunctional personal relationship. ${ }^{36}$ Even an existing familiar unpleasant status quo can be comforting and preferable in comparison with an unknown future that possibly entails much worse outcomes. Many people remain in dysfunctional personal and professional situations due to fear and aversion to risk or aversion to ambiguity.

The rest of this Article is organized as follows. Part I recounts my unique adventures in higher education as student and professor because "[w]e do not see things as they are, we see them as we are." ${ }^{37}$ Part II analyzes why law schools should teach law students about happiness and mindfulness. This Article advocates that law professors teach law students about happiness to equip them with mindsets, skills, and techniques to craft, develop, and sustain fulfilling, meaningful, and satisfying careers and professional identities. This Article advocates that law professors teach law students about mindfulness to improve their professional and personal

33 Nathalie Martin, Mindful Lawyering, in The Best Lawyer You Can Be: A Guide to Physical, Mental, Emotional, and Spiritual Wellness 27 (Stewart Levine ed., 2018).

34 Corie Rosen Felder, The Accidental Optimist, 21 VA. J. Soc. PoL'y \& L. 63, 68 (2014).

35 See, e.g., Kate Mayer Mangan, How the New Science of Self-Compassion Could Patch the Leaky Pipeline, 101 Women LaWyer's J., No. 2, 2016, at 12.

36 See, e.g., Louis Tomlinson and Bebe Rexha with Digital Farm Animals performing the song Back to You on The Tonight Show Starring Jimmy Fallon, NBC television broadcast, Aug. 4, 2017, https://www.youtube.com/watch?v=yIe5KBLnjMY.

37 Anais Nin, Seduction of the Minotaur 124 (1961, 6th printing 1972). 
decision-making, ethics, and leadership. ${ }^{38}$ Part III examines how to teach law students happiness and mindfulness. Finally, this Article offers brief conclusions about how law students can sustain happiness and mindfulness once they graduate from law school.

\section{My Unique Adventures in Higher EducAtion}

I discuss a few of my unique adventures in higher education in the spirit of sharing idiosyncratic, personal, and specific memories to provide background, context, and as a precursor for a more abstract, general, and universal discussion of legal education. Our path dependent history shapes us in our present and our multiple possible futures. As best-selling authors Stanford business school professor Chip Heath and his brother, Duke center for the advancement of social entrepreneurship senior fellow, Dan Heath explain in their book, ${ }^{39}$ all of us have certain memorable positive moments in our lives that change us thorough connection, elevation, insight, and pride.

I have been fortunate to be a student (in chronological order) at these schools: New York University, Princeton University, Harvard University, the University of Chicago, and Stanford University; teach economics or finance (in chronological order) at Cañada Community College, the University of Iowa, Southern Methodist University, Tulane University, the University of California, Berkeley, the University of California Los Angeles, the University of Southern California, and Stanford University; and teach law (in chronological order) at the University of Pennsylvania, the University of Southern California, the University of Chicago, the University of Virginia, the University of Minnesota, Temple University, Yale University, and the University of Colorado, Boulder.

\section{A. Princeton University Freshman at the Age of 14}

I was a freshman at Princeton University at the age of 14. My first mathematics class at Princeton was a section of honors calculus that mathematics majors usually take in the spring of their sophomore year. The course provided a theoretical introduction to multivariable analysis. ${ }^{40}$ A prerequisite for this course was a rigorous linear algebra course that focused on writing proofs and bridged the gap between single variable calculus and more advanced mathematics courses.$^{41}$ One day, my honors calculus professor announced our class would not get back a homework assignment

38 Peter H. Huang, Can Practicing Mindfulness Improve Lawyer Decision-Making, Ethics, and Leadership? 55 Houston L. Rev. 63-154 (2017); Peter H. Huang, Boost: Improving Mindfulness, Thinking, and Diversity, 10 WM. \& MARY Bus. L. Rev. (forthcoming 2018).

39 Chip Heath \& Dean Heath, The Power of Moments: Why Certain Experiences HaVE EXTRAORDINARY IMPACT (2017).

40 The course covered metric and topological spaces, continuous and differential mappings between $n$-dimensional real vector spaces, the inverse mapping theorem, the implicit function theorem, measure and content zero, Fubini's theorem, partitions of unity, change of variable, exterior derivatives, differential forms, pullbacks, tangent spaces, tensor calculus, and the generalized modern Stokes' theorem on manifolds-with-boundaries.

41 A prerequisite course would cover linear transformations, matrices, determinants, eigenvalues, vector spaces, inner product spaces, dual spaces, and quadratic forms. 
because the course's grader had committed suicide! It was rumored that every four years, a Princeton mathematics graduate student or undergraduate mathematics major jumped off the mathematics building, Fine Hall, to commit suicide due to depression, anxiety, and chronic stress from the pressure to excel academically and/ or live up to their or others' perfectionist expectations.

At the risk of sounding trite, happy people do not commit suicide; unhappy people do. Recently, researchers developed a mindfulness-to-meaning theory proposing that practicing mindfulness, through the promotion of positive reappraisal, fosters eudaimonic well-being, flourishing, a greater sense of purpose, and meaningful engagement with life..$^{42}$ Additional recent social genomics research found that people with eudaimonic well-being in terms of being meaningfully engaged with life, having a sense of purpose, and who were flourishing, were more likely to exhibit decreased inflammation and increased antiviral response, which is the opposite gene profile of those who suffer from social isolation. ${ }^{43}$ It is crucial to emphasize this research finds a correlation, and not a causal link, between thriving and favorable gene expression. ${ }^{44}$ Also, older adults who practice mindfulness are less lonely and have less pro-inflammatory gene expression. ${ }^{45}$ Additionally, practicing mindfulness provides individuals with an awareness and the perspective that nothing is permanent, including pain, suffering, and negative emotions. Mindfulness mitigates ruminations and can transform vicious cycles of thought, feelings, and bodily sensations into virtuous cycles of thought, feelings, and bodily sensations. ${ }^{46}$ The practice of mindfulness reduces stress and increases resilience to stressors. ${ }^{47}$

I had not thought about suicide before learning of that suicide. I came to think about suicide at various times during the next three years, as do many teenagers. According to the United States Center for Disease Control and Prevention, teen suicide is the number two cause of death for youths ages 15 to 24 , and is only

42 Eric L. Garland et al., Mindfulness Broadens Awareness and Builds Eudaimonic Meaning: A Process Model of Mindful Positive Emotion Regulation, 26 Psychol. Inquiry 293 (2015).

43 Barbara Fredrickson et al., A Functional Genomic Perspective on Human WellBeing, 110 Proc. Nat'l ACAD. ScI. 13684 (2013) (presenting this research); Barbara Fredrickson et al., Psychological Well-Being and the Human Conserved Transcriptional Response to Adversity, 10 PLoS One e0121839 (2015) (confirming and following up on this research); Barbara Fredrickson et al., Correction: Psychological Well-Being and the Human Conserved Transcriptional Response to Adversity, 11 PLoS One e 0157116 (2016) (presenting a corrected version of the follow-up research). See also Will Storr, $A$ Better Kind of Happiness, THE New YoRKer, July 7, 2016 (reporting on this research). See also Will Storr, A Better Kind of Happiness, The New Yorker, July 7, 2016.

44 Dan Pouliot, Mind Over Genetics, and Inaccuracy in Journalism, Sept. 28, 2013, available at http://danpouliot.com/blog/2013/09/mind-over-genetics-and-innaccuracyin-journalism/.

45 J. David Creswell et al., Mindfulness-Based Stress Reduction Training Reduces Loneliness and Pro-Inflammatory Gene Expression in Older Adults: A Small Randomized Controlled Trial, 26 Brain, Behav. \& Immunity 1095, 1099 (2012).

46 Garland et al., supra note 42, at 293, 299, fig. 1.

47 Nick Petrie, Wake Up! The Surprising Truth about What Drives Stress and How Leaders Build Resilience, 15, Center for Creative Leadership White Paper (2013), http://www. nicholaspetrie.com/wp-content/uploads/2013/08/Wake-Up-The-Surprising-TruthAbout-What-Drives-Stress-and-How-Leaders-Build-Resilience.pdf. 
surpassed by accidents. ${ }^{48}$ Sadly, Gunn High School and Palo Alto High School, two high schools located near Stanford University, had a ten-year suicide rate in in December 2015 between four and five times the national average. ${ }^{49}$ Although suicide, teen suicide, and suicide clusters (defined to be multiple suicides that happen in close proximity and succession) know of no geographical or social boundaries, constant pressures to be all that you can be academically often exacerbate teen suicides. Palo Alto High School, affectionately known as "Paly," is just across the street known as El Camino Real (The King's Road) from Stanford, while Gunn is only two miles from Stanford and was in 2014 one of America's top five STEM high schools according to U.S. News \& World Report.

There are many causes of suicide "--biological, environmental, psychological and situational" ${ }^{50}$ with correspondingly many contributing factors, some of which are controllable and preventable. Dr. Adam Strassberg, a psychiatrist and parent whose teenagers attended school in the Palo Alto Unified School District, eloquently wrote:

\begin{abstract}
Why does it need to take a suicide, or worse yet this cluster of suicides, to justify and invigorate public conversation over improving the mental health, happiness and quality of life for our teens?! More sleep, more free unscheduled time to play and to grow, less homework, more balance, better stress tolerance -- these are inherent goods and worthy continual goals for our school district and community. These goals should be active and ongoing and not be predicated upon any "crisis" in student mental health, "perceived" or "actual." 51
\end{abstract}

An analogous paragraph to the above paragraph applies to law students and lawyers in the sense that improving the happiness, mental health, and quality of life for law students and lawyers can and should be priorities for them, their clients, and our society-at-large. Happy and healthy law students learn how to be happy and healthy lawyers who can more effectively serve their clients. Learning to live with a growth mindset, more balance, better and more sleep, more resilience, and stress management are perspectives and skills that law professors can teach and law students can learn. Happy and healthy lawyers can realize their potential to accomplish much social good. Unhappy and unhealthy lawyers can realize their potential to cause much social harm.

Suicidologists (those who study suicide behavior and prevention ${ }^{52}$ ) disagree over whether suicide is an irrational or a rational choice. Suicide hotlines are based

48 American Psychological Association, Teen Suicide is Preventable, Research in Action, Psychological Science, http://www.apa.org/research/action/suicide.aspx.

49 Hanna Rosin, The Silicon Valley Suicides: Why Are So Many Kids with Bright Prospects Killing Themselves in Palo Alto? The AtLantic, Dec. 2015, https://www.theatlantic. com/magazine/archive/2015/12/the-silicon-valley-suicides/413140/.

50 Adam Strassberg, Guest Opinion: Keep Calm and Carry On, Palo Alto Online, Mar. 16, 2015, 2:51 p.m., https://paloaltoonline.com/news/2015/03/16/guest-opinion-keepcalm-and-parent-on\#sthash.UpnboeKF.dpuf.

${ }^{51} \quad I d$.

52 American Association of Suicidology Website, http://www.suicidology.org/. 
on the underlying idea that attempting suicide is due to experiencing relatively short periods of mental illness and intense psychological pain leading to temporary and treatable irrational thoughts and lapses in reason. The title of American hip-hop artist Logic's popular music hit song with vocals from Canadian and American singersongwriters Alessia Cara and Khalid, 1-800-273-8255, ${ }^{53}$ is the phone number of the confidential, free, 24/7 National Suicide Prevention Lifeline: 1-800-273-TALK. ${ }^{54}$ On April 28, 2017, the song's release date, the National Suicide Prevention Lifeline experienced its second-highest call volume, with calls up approximately $33 \%$ from a year ago. ${ }^{55}$

A large body of research links perfectionism to suicide ideation and attempts. ${ }^{56}$ A recent meta-analysis of forty-five studies involving eleven thousand seven hundred and forty-seven individuals consisting of undergraduates, medical students, community adults, and psychiatric patients finds:

perfectionistic concerns (socially prescribed perfectionism, concern over mistakes, doubts about actions, discrepancy, perfectionistic attitudes), perfectionistic strivings (self-oriented perfectionism, personal standards), parental criticism, and parental expectations displayed small-tomoderate positive associations with suicide ideation. Socially prescribed perfectionism also predicted longitudinal increases in suicide ideation. And perfectionistic concerns, parental criticism, and parental expectations displayed small, positive associations with suicide attempts. ${ }^{57}$

The study's authors conclude their findings "lend credence to theoretical accounts suggesting self-generated and socially based pressures to be perfect are part of the premorbid personality of people prone to suicide ideation and attempts. Perfectionistic strivings' association with suicide ideation also draws into question the notion that such strivings are healthy, adaptive, or advisable." ${ }^{58}$

A basic economic model of suicide assumes that a rational individual chooses to commit suicide when the net present discounted value of that person's remaining expected lifetime happiness becomes negative or less than some benchmark level. ${ }^{59}$ A financial economic model of suicide adds the real option value of staying alive. ${ }^{60}$ A revised economic model of suicide assumes there is a nontrivial probability of surviving a suicide attempt and that an unsuccessful suicide attempt may affect a

LOGIC, 1-800-273-8255, on EvERYBODY (Visionary 2017).

54 National Suicide Prevention Lifeline Website, https://suicidepreventionlifeline.org/.

55 Ben Tinker, The Life-Saving Message in Logic's Hit Song, CNN, Updated 11:59 ET, Aug. 27, 2017, http://www.cnn.com/2017/08/25/health/logic-suicide-hotlinevma-18002738255/index.html.

56 See, e.g., Sidney J. Blatt, The Destructiveness of Perfectionism: Implications for the Treatment of Depression, 50 Aм. Psychol. 1003 (1995).

57 Martin M, Smith et al., The Perniciousness of Perfectionism: A Meta-Analytic Review of the Perfectionism-Suicide Relationship, J. Personality (forthcoming).

$58 \quad I d$.

59 Daniel S. Hamermesh \& Neal M. Soss, An Economic Theory of Suicide, 82 J. PoL. ECON. 83 (1974).

60 Avinash K. Dixit \& Robert E. Pindyck, Investment Under UnCertainty 24-25, 41 n.9 (1994). 
person's happiness, positively or negatively. ${ }^{61}$ An evolutionary economic model in which people are motivated to increase the likelihood of elation and reduce the likelihood of depression reconsiders the idea that depression and suicide are ways individuals can improve their kin's welfare. ${ }^{62}$

After my first year, I successfully applied to graduate in three years and became a junior in my second year. I also successfully applied to and became a university scholar as part of a program "designed for students with exceptional talent in an academic or creative area that cannot be pursued within the confines of the regular curriculum. ${ }^{963}$ In my third year as a senior, I took only graduate courses and reading courses in mathematics, economics, mathematical economics, and politics. I earned an A.B. in mathematics from Princeton at the age of 17.

My junior independent work advisor was professor Charles Louis Fefferman, a child prodigy who was a freshman at the University of Maryland at the age of 14. Fefferman earned his B.S. with the highest distinction in mathematics and physics at the age of 17. Fefferman earned his mathematics Ph.D. from Princeton at the age of 20. Fefferman became a full professor at the University of Chicago at the age of 22. Fefferman was the youngest person ever appointed as a full professor in the United States. In 1973, Fefferman returned to Princeton University as a full professor at the age of 24. Fefferman was the first person to whom the National Science Foundation presented the Alan T. Waterman Award ${ }^{64}$ Fefferman also received the Fields medal, ${ }^{65}$ which is often considered to be the highest honor a mathematician can receive and is commonly known as the mathematician's Nobel prize. $^{66}$

In my second year at Princeton, I sat in on Professor Fefferman teaching the course on advanced multivariable calculus that I took in the fall of my first year. Professor Fefferman's conversational teaching style was congenial, easygoing, and fun.$^{67}$ His classroom presentations and interactions with students were effortless and natural. It was a very different version of the course than the one I took just one year earlier. There was no hypercompetitive, Darwinian evolutionary survival-of-the-fittest, sink or swim attitude in the course. Instead, it was clear

61 Dave E. Marcotte, The Economics of Suicide, Revised, 69 Southern Econ. J. 628 (2003).

62 Donald Wittman, Darwinian Depression, 168 J. AfFective Disorders 142, 143, 145-46 (2014).

63 Office of the Dean of the College, University Scholar Program, Princeton University, https://odoc.princeton.edu/curriculum/special-academic-programs/university-scholarprogram.

64 This is the highest honorary award in the United States given to scientists not older than thirty-five.

65 The Fields Medal is awarded to mathematicians under 40 years of age, once every four years, at the International Congress of the International Mathematical Union.

66 More precisely, the mathematician's Nobel prize is often thought of as the Fields medal, in conjunction with the Abel prize, which the Norwegian government started in 2003 to award annually and has no age restriction.

67 For each of the main theorems about the geometry of differentiable mappings between n-dimensional real vector spaces, professor Fefferman presented alternate versions of the proofs, emphasizing the algebraic, differential, or topological aspects of the results. $\mathrm{He}$ also related each theorem to its lower-dimensional versions in the plane or space as well as their applications to and interpretations from classical and modern physics. 
that Professor Fefferman cared about his teaching and engaging students as and where they were.

I have vivid memories of a wide-ranging one-and-one-half hour conversation, on a bus ride between Port Authority in New York City and Princeton's Nassau Street, with Professor Fefferman about his research, teaching, and taking out the garbage before proving theorems in his then new role of husband to his wife Julie Anne Albert, who herself was a child prodigy in music who studied violin at the famed Juilliard School at the age of 9. He discussed the wide range of mathematical problems on which he worked. ${ }^{68} \mathrm{He}$ observed that instead of him choosing problems to work on, problems effectively chose him to be worked upon in the sense that he could not stop thinking about certain problems once he learned of them by reading, serendipity, talking with colleagues, or simply following his own thinking. He observed that he could solve only some of the problems he worked on, even ones he worked for quite long periods of time.

He described how much he would enjoy lying on his couch and thinking deeply for hours at a time about change, relationships, shapes, and not so much about numbers per se. After he mentally investigated and cast off many of his ideas, he would eventually come upon a hopeful idea and be ready to pursue it further on paper. He emphasized how important optimism and perseverance are to working on difficult research problems. He said that solving an easier version of a complicated problem was his first step in making progress. He said that he would often go down many dead ends for quite some time before realizing that. He cautioned research can be highly nonlinear in its progress and often involves doubling back upon realizing having earlier made a mistake.

I was fascinated listening to Fefferman and learning about how he did his mathematics research! While his example was inspirational, I realized I had neither his rare mathematical talent nor the desire to become a pure mathematician because of a nascent interest about and attraction to mathematical economics. I earned in the spring of that year at Princeton a grade of A+ in the course Economic Dynamics, ${ }^{69}$ taught by a new assistant professor Martin Hellwig. ${ }^{70}$ Taking that course (and earning that course grade) provided the impetus and motivating force for me to focus on studying mathematical economics. The mathematics that course utilized to model the dynamics of economic systems was difference equations. My familiarity with the stability analysis of a dynamical system described by difference equations helped to convince me much later in life to participate in couples counseling. I

68 Professor Fefferman is known for his path-breaking research in modern mathematical analysis, mathematical physics and geometry, partial differential equations, several complex variables, and Fourier analysis, which is the study of how complicated vibrations can be decomposed, represented, or approximated by sums of simpler trigonometric functions. He offered an example of what Fourier analysis is about by explaining how the complicated motion of a violin string consists of a fundamental note, a first overtone, a second overtone, and so forth.

69 This course covered difference equations, cobweb models, business cycle models, the Hansen-Samuelson multiplier-accelerator model, and Solow's growth model.

70 Martin Hellwig, Max Planck Institute for Research on Collective Goods, https://www. coll.mpg.de/team/page/martin_hellwig. 
was fascinated to learn from an article ${ }^{71}$ and related book ${ }^{72}$ about how to utilize the mathematics of dynamical systems to analyze the impacts on the happiness, unhappiness, or dissolution of a relationship of these psychological factors: emotional inertia, how each member of a couple influences the other, personality, and relationship history.

My interests in applying mathematics to economics by becoming a mathematical economic theorist developed further upon taking a pair of graduate mathematical economics courses Linear and Convex Systems ${ }^{73}$ and Advanced Theory. ${ }^{74}$ Both courses opened my eyes to a field that possesses the abstraction, beauty, elegance, logic, precision, rigor, and sophistication of pure mathematics applied to analyze important economic and societal issues. Being able to apply mathematics to understand how to solve real-world economic problems and social challenges seemed like a wondrous way to spend a life. I knew then, or thought I knew, I would be happy being a mathematical economic theorist for a lifetime. Life of course unfolded somewhat differently.

My senior thesis title was Applications of Catastrophe Theory to Economics. A French mathematician, René Thom, invented catastrophe theory, ${ }^{75}$ which studies how dynamical systems can bifurcate. Catastrophe theory qualitatively models how underlying forces that change continuously, gradually, and slowly can nonetheless cause discontinuous, large, and sudden changes. Erik Christopher Zeeman popularized catastrophe theory and its applications to biology, economics, and sociology. ${ }^{76}$ Zeeman's catastrophe theory model of stock market bubbles and crashes was published 1974 in the inaugural issue of the Journal of Mathematical Economics. ${ }^{77}$ My senior thesis analyzed that model and other applications of catastrophe theory to economics.

I have remained ever since then interested in applications of catastrophe theory to study the stability of general economic equilibria, ${ }^{78}$ asset market fluctuations, ${ }^{79}$

71 John Gottman, Catherine Swanson, \& James Murray, The Mathematics of Marital Conflict: Dynamic Mathematical Nonlinear Modeling of Newlywed Marital Interaction, 13 J. FAM. PSYCHOL. 13 (1999).

72 John M. Gottman, James D. Murray, Catherine C. Swanson, Rebecca Tyson, \& Kristen R. Swanson, The Mathematics of Marriage: Dynamic Nonlinear Models (2005).

73 This course covered convex analysis, fixed point theorems, separating hyperplane theorems, general equilibrium theory, the fundamental theorems of welfare economics, and algorithms for computing fixed points and general equilibria of competitive economies.

74 This course covered dynamic programming, optimal control theory, Euler equations, Pontryagin's maximum principle, calculus of variations, von Neumann's growth model, Ramsey's growth model, transversality conditions, and turnpike theorems.

75 René Thom, Structural Stability and Morphogenesis: An Outline of A General THEORY OF MODELS (1972).

76 E. C. Zeeman, Catastrophe Theory, Sci. Am., Apr., at 65 (1976); E. C. Zeeman, Catastrophe Theory: Selected Papers, 1972-1977 (1977).

77 E. C. Zeeman, On the Unstable Behaviour of Stock Exchanges, 1 J. Mathematical ECON. 39 (1974).

78 See, e.g., Yves Balasko, Economic Equilibrium and Catastrophe Theory: An Introduction, 46 ECONOMETRICA 557 (1978).

79 See, e.g., Jozef Barunik \& Miloslav Vosvrda, Can A Stochastic Cusp Catastrophe Model Explain Stock Market Crashes? 33 J. Econ. Dynamics \& Control 1824 (2009) (estimating a cusp catastrophe based upon real-world financial data); Thorsten 
and aggregate business cycles. ${ }^{80} \mathrm{I}$ also was fascinated and intrigued much later in life to learn about applications of catastrophe theory to mathematically analyze dating and mating ${ }^{81}$ in addition to how and why a marriage can breakdown suddenly. ${ }^{82}$ I have always been more comfortable with communicating in the language of mathematics than in the various languages of love. ${ }^{83}$

My senior thesis advisor was Harold W. Kuhn, well-known for the KarashKuhn-Tucker (KKT) theorem and the associated KKT conditions. ${ }^{84}$ The KKT conditions provide a standard mathematical way to analyze the optimal choices of economic actors. For example, economists apply the KKT conditions to study three canonical problems. First, consumers maximizing utilities subject to budget constraints. Second, firms maximizing profits subject to production technology constraints, or firms maximizing sales revenues subject to profit constraints. Third, investors minimizing total portfolio risk subject to budget and expected return constraints. Harry Markowitz received the 1990 Nobel memorial prize in economic sciences in part for analyzing how to build optimal asset portfolios. ${ }^{85}$ The KKT theorem and KKT conditions also are ubiquitous in operations research, industrial engineering, and management planning to characterize solutions to such pervasive nonlinear optimization problems as designing quality or safety inspections, managing and controlling inventories, optimizing the packing and shipping of boxes, planning factory production schedules, scheduling power plants, and routing airlines crews, flights, itineraries, and planes.

I took professor Kuhn's undergraduate Mathematical Programming course ${ }^{86}$ in the fall of my junior year and his two-semester sequence of graduate mathematical

Rheinlaender \& Marcus Steinkamp, A Stochastic Version of Zeeman's Market Model, 8 Stud. Nonlinear Dynamics \& Econometrics Art. 4 (2004) (analyzing a randomized version of Zeeman's model involving fundamental and momentum traders); J. Barkley Rosser Jr., The Rise and Fall of Catastrophe Theory Applications in Economics: Was the Baby Thrown Out with the Bathwater? 31 J. 3255, 3270-72 (concluding that many criticisms of Zeeman's stock market model are fallacious (2007).

80 Hal R. Varian, Catastrophe Theory and the Business Cycle, 17 ECON. INQUIRY 14 (1979).

81 Abraham Tesser \& John Achee, Aggression, Love, Conformity, and Other Social Psychological Catastrophes, in Dynamical Systems in Social Psychology 95 (Robin R. Vallacher \& Andrzej Nowak eds., 1994).

82 GotTman ET AL., supra note 72, at 81-98, 141-43.

83 Gary Chapman, The 5 Love Languages: The Secret to Love that Lasts (2015).

84 William Karash, Minima of Functions of Several Variables with Inequalities as Side Constraints, M. Sci. dissertation, Mathematics, Univ. of Chicago (1939); Harold W. Kuhn \& Albert H. Tucker, Nonlinear Programming, Proc. 2ND Berkeley Symposium 481 (1951). The KKT theorem and KKT conditions are iconic in mathematical optimization as the first order necessary conditions for a solution of a nonlinear programming problem to be optimal (assuming that a regularity condition known as the constraint qualification is met). The KKT theorem and KKT conditions generalize the classic method of Lagrange multipliers, which apply only to the optimization of a function subject to equality constraints, to also permit inequality constraints.

85 Harry M. Markowitz, Foundations of Portfolio Theory, 46 J. FIN. 469 (1991) (Nobel lecture); Harry M. Markowitz, Portfolio Selection, 7 J. Fin. 77 (1952); Harry M. Markowitz, PortFolio Selection: EfFicient DiversificAtion of InVESTMENTs (2d. ed., 1991).

86 This course covered linear programming, tableau algebra, duality theorems, Dantzig's simplex method, matrix games, assignment problems, matching problems, transportation problems, network flow problems, the Hungarian method, quadratic programming, and nonlinear programming. 
economics courses in my senior year. In each of those classes, Kuhn was impeccably organized and thoroughly prepared. Kuhn was a masterful expositor and Kuhn's lectures were just a joy to behold because they were simply exemplary in their clarity and precision, while his neat blackboard writing provided cameraready notes. Kuhn was amazing in distilling the key insights underlying complex theoretical results. Kuhn also provided insightful low-dimensional examples, intuition, pictures, and stories to illustrate and motivate our truly understanding the central essence and important features of highly abstract, formal, and general versions of key theorems. Kuhn told us engaging anecdotes and personal stories about iconic figures in the field of mathematical economics during the frenzy and heyday of cold war research into activity analysis, decision theory, game theory, mathematical programming, and welfare economics.

Although professors Fefferman and Kuhn had very different mathematical research interests, teaching styles and classroom presentation methods, both clearly had a passion for advancing the frontiers of research by creating knowledge and sharing their enthusiasm for learning by inspirationally communicating core concepts, organizing ideas, and multiple perspectives. I view both of them as exemplars and role models for professors who excel at research and teaching. Professors who are both excellent researchers and teachers are rare.

\section{B. HaRVARd University GRaduAte StUdent at THE AGE OF 17}

I enrolled at Harvard University in what is now known as the Harvard John A. Paulson School of Engineering and Applied Sciences to pursue a Ph.D. in applied mathematics at the age of 17. My Ph.D. dissertation was titled Asymptotic and Structural Stability of Signalling Equilibria. My principal thesis advisor was Kenneth J. Arrow, a recipient of the 1972 Nobel memorial prize in economic sciences at the age of 51, and who remains the youngest person ever to receive the Nobel memorial prize in economic sciences.$^{87}$ Another of Arrow's former economics graduate students, Michael Spence, is a 2001 economics Nobel memorial prize in economic sciences recipient for his path-breaking research in the economics of (asymmetric) information about what he called market signaling. ${ }^{88}$ Spence defined job market signals to be alterable, observable characteristics that may or may not affect an individual's unobservable individual marginal productivity, which depends on unalterable, unobservable personal characteristics. ${ }^{89}$ The prototypical example of a job market signal is years of higher education.

By assuming that higher education may or may not affect productivity, Spence was agnostic about education being a form of human capital. Spence focused instead on the sorting aspect of higher education signals. Two other recipients of the Nobel memorial

87 Kenneth J. Arrow, General Economic Equilibrium: Purpose, Analytic Techniques, Collective Choice, 64 Am. Econ. Rev. 253 (1974) (Nobel lecture).

88 Michael Spence, Signaling in Retrospect and the Informational Structure of Markets, 92 Am. Econ. Rev. 434 (2002) (Nobel lecture); Michael Spence, Job Market Signaling, 87 Q J. ECON. 355 (1973).

89 Michael Spence, Market Signaling: The Informational Structure of Job Markets and Related Phenomena 119 (1972). 
prize in economic sciences, Kenneth Arrow ${ }^{90}$ and Joseph Stiglitz ${ }^{91}$ also wrote about higher education serving as a filter, screen, or label..$^{92}$ The traditional human capital theory view is that higher education increases productivity through acquiring cognitive skills and/or becoming socialized about such soft skills as emotional intelligence and punctuality. ${ }^{93}$ Arrow stated that he personally did not believe that higher education only serves to screen people. ${ }^{94}$ Arrow also stated that obviously professional schools transmit concrete skills that potential employers value. ${ }^{95}$ Data suggests that higher education is both a form of human capital and job market signal. ${ }^{96}$

Spence's thesis analyzed the existence, economic inefficiency, and some other properties of job market signaling equilibria, which are defined as employers' probability beliefs over productivity conditional on higher education that do not generate any disconfirming market data. There is now a vast economics literature about market signaling. ${ }^{97}$ My thesis examined the asymptotic stability and structural stability of market signaling equilibria.$^{98}$ Asymptotic stability refers to convergence of conditional probability beliefs revised under a dynamic adjustment process, such as updating prior beliefs via Bayesian inference to form posterior beliefs. Mathematical tools of asymptotic stability analysis include probability theory and martingale convergence theorems. ${ }^{99}$ Structural stability refers to robustness of market signaling equilibria under perturbations of the underlying parameters that define a signaling economy, such as individuals' marginal productivity functions and signaling cost functions. Gerard Debreu, 1983 economics Nobel memorial prize in economic sciences recipient, ${ }^{100}$ pioneered the structural stability analysis of general economic equilibria. ${ }^{101}$ Debreu introduced to economic analysis the mathematical tools of degree theory, differential topology, genericity analysis, global analysis, Sard's theorem, and transversality theory. ${ }^{102}$

$90 \quad$ Arrow, supra note 87.

91 Joseph E. Stiglitz, Information and the Change in the Paradigm of Economics, 92 Ам. ECON. REv. 460 (2002) (Nobel lecture).

92 Kenneth J. Arrow, Higher Education as a Filter, 2 J. Pub. EcON. 193 (1972); Joseph Stiglitz, The Theory of 'Screening', Education, and the Distribution of Income, 65 AM. ECON. REv. 283 (1975).

93 Arrow, supra note 92, at 193-94.

$94 \quad$ Id. at 194.

$95 \quad$ Id. at 194.

96 John G. Riley, Testing the Educational Screening Hypothesis, 87 J. PoL. EcON. S 227 (1979).

97 SPENCE, supra note 89.

98 Peter H. Huang, Asymptotic Stability of Bayesian Updating for Spencian Examples, 17 Econ. Letters 47 (1985); Peter H. Huang, The Robustness of Multidimensional Signaling Equilibria, 25 ECON. LetTers 217 (1987); Peter H. Huang, Upper SemiContinuity of the Separating Equilibrium Correspondence, 47 J. ECON. THEORY 406 (1989); Peter H. Huang, Structural Stability of Financial and Accounting Signaling Equilibria, 9 REs. FIn. 37 (1991).

99 See, e.g., Margaret Bray \& David M. Kreps, Rational Learning and Rational Expectations, in Arrow AND THE AsCent OF MODERn ECONOMIC TheORY 597 (George R. Feiwel ed., 1987); Margaret Bray, Learning, Estimation, and the Stability of Rational Expectations, 26 J. ECON. Theory 318 (1982).

100 Gerard Debreu, Economic Theory in the Mathematical Mode, 74 Am. Econ. Rev. 267 (1984) (Nobel lecture).

101 Gerard Debreu, Regular Differentiable Economies, 66 Am. Econ. Rev. 280 (1976).

102 See, e.g., Yves Balasko, Foundations of the Theory of General Equilibrium (2d 
I remember asking Arrow why Spence did not study the asymptotic stability and structural stability of market signaling equilibria. Arrow replied that both were difficult and challenging problems in mathematical economics. I took Arrow's answer to be a call to action. Before that moment, I, as is true of many students who finished the course requirements of their Ph.D. program, was finding it challenging to decide on an interesting, manageable, and suitable dissertation topic. In my first year of graduate school, I took the comprehensive microeconomic theory course, ${ }^{103}$ that is designed for non-economics Ph.D. students in other parts of the university. Economics assistant professor Steven Shavell, who would later become a professor at Harvard law school and a leader in the field of law and economics, ${ }^{104}$ taught the course. It was my introduction to formal economic models of risk behavior, insurance, and efficient risk allocation. In my second year of graduate school, I took the core microeconomics sequence, limited to students in the economics and business economics Ph.D. programs. It was co-taught by professor Jerry Green and Spence. In my third year of graduate school, I sat in on a graduate industrial organization course, also co-taught by Spence.

I took in the spring of my first year of graduate school Arrow's course Information, Communication, and Organization. ${ }^{105}$ This was a fascinating course about how to analytically model the communication of dispersed information in organizations, such as couples, firms, societies, teams, and the military. Arrow sometimes presented a stream of consciousness that he just thought of while walking through Harvard yard on his way to class. Arrow's brilliance made it difficult for him once in a while to determine the knowledge of the audience. A fellow applied mathematics graduate student sat in on a lecture during which Arrow wrote: x" where the first prime denoted the transpose of the vector $x$, the second its derivative, and the third to distinguish $\mathrm{x}$ " from x' and x". Arrow noted that the order of the primes did not matter, which is classic Arrow! In that class, Arrow asked if students knew the sigma summation symbol, $\sum$, from high school algebra, and later if students knew how to apply Itô's lemma to derive the stochastic partial differential equation whose solution is the famous Black-Scholes-Merton options pricing formula, ${ }^{106}$ for which Myron Scholes and Robert Merton jointly received the 1997 Nobel memorial prize in economic sciences (Fisher Black had passed away and the Nobel memorial prize in economic sciences is not awarded posthumously). ${ }^{107}$

ed., 2016); Yves Balasko, The Equilibrium Manifold: Postmodern Developments in the Theory of General Economic Equilibrium (2009); Andreu Mas-Colell, The Theory of General Economic Equilibrium: A Differentiable Approach (1990).

103 This course rigorously covered modern economic theories of consumption, production, behavior under risk, and general equilibrium theory.

104 Harvard Law School, Steven Shavell faculty page, http://hls.harvard.edu/faculty/ directory/10793/Shavell.

105 This course covered the general resource allocation problem, market allocation, uncertainty, demand for and value of information, transactions costs, bosses, authority, communication, team theory, budget planning, moral hazard, principal agent theory, hierarchical supervision, formal organization of decision making, expedience, and incentives.

106 Fisher Black \& Myron Scholes, The Pricing of Options and Corporate Liabilities, $81 \mathrm{~J}$. Pol. ECon. 637 (1973); Robert C. Merton, Theory of Rational Option Pricing, 4 BelL J. Econ. \& Mgmt. ScI. 141 (1973). See also Robert A. Jarrow, In Honor of the Nobel Laureates Robert C. Merton and Myron S. Scholes: A Partial Differential Equation That Changed the World, 13 J. Econ. Liт. 229 (1999).

107 Robert C. Merton, Applications of Options Pricing Theory Twenty-Five Years Later, 88 
I also took in the spring semester of my first year of graduate school another fascinating course, A Mathematical Approach to General Equilibrium. ${ }^{108}$ Graciela Chichilnisky, who has two Ph.D. degrees, one in mathematics from M.I.T. and one in economics from the University of California Berkeley, ${ }^{109}$ taught the course. It was a particularly exciting and fun time to take her course because Chichilnisky was just starting to apply differential topology methods to analyze social choice problems. ${ }^{110}$ In that course we learned about diverse, novel applications of differential topology, such as how the Poincaré-Hopf index theorem applies to studying nonlinear dynamics in ecological and chemical networks. ${ }^{111}$

It was and still is rare to have a woman professor teach a graduate course in mathematical economics. I have been struck by how few women there are at conferences for economics professors and how many more women there are at conferences for psychology and/or marketing professors, even though all three disciplines require quantitative and statistical coursework and proficiency. Gender discrimination and inequality in economics and academia are unfortunate for women and society. University of Michigan professor of complex systems, political science, and economics Scott Page wrote a book rigorously analyzing and providing evidence for how important diversity of viewpoints is to solving individual and collective problems. ${ }^{112}$

Chichilnisky wrote a candid, fascinating chapter about two lessons that she learned from having to deal with a glass ceiling and gender inequity at Columbia University: ${ }^{113}$ one way to thrive, succeed, and be happy is to turn negative responses directed at you into positive resources for you, and the genuine source of happiness is the feeling of being useful to others. ${ }^{114}$ Computer science and technology entrepreneurs, start-up employees, and even as early as college majors have

Am. Econ. Rev. 323 (1998) (Nobel lecture); Myron Scholes, Derivatives in a Dynamic Environment, 88 Am. Econ. Rev. 350 (1998) (Nobel lecture).

108 This course covered the mathematics of combinatorial topology, differentiable topology, and algebraic topology. It also covered economic applications to general equilibrium theory and social choice theory, in addition to applications to biology, chemistry, and physics.

$109 \mathrm{http} / /$ chichilnisky.com/graciela-chichilnisky/.

110 See, e.g., Graciela Chichilnisky, On Fixed Point Theorems and Social Choice Paradoxes, 3 ECon. Letters 347 (1979); Graciela Chichilnisky, Social Choice and the Topology of Spaces of Preferences, 37 Adv. Mathematics 165 (1980); Graciela Chichilnisky, Continuous Representation of Preferences 47 Rev. Econ. Stud. 959 (1980); Graciela Chichilnisky, Social Aggregation Rules and Continuity, 97 Q.J. EcoN. 337 (1982); Graciela Chichilnisky, Structural Instability of Decisive Majority Rules, 9 J. Mathematical Econ. 207 (1982); Graciela Chichilnisky, Topological Equivalence of the Pareto Condition and the Existence of a Dictator, 9 J. Mathematical Econ. 223 (1982); Graciela Chichilnisky, Social Choice and the Closed Convergence Topology, 8 Soc. Choice \& Welfare 307 (1991); Graciela Chichilnisky, Social Diversity, Arbitrage, and Gains from Trade: A Unified Perspective, 84 Am. Econ. Rev. 427 (1994).

111 Leon Glass, A Topological Theorem for Nonlinear Dynamics in Chemical and Ecological Networks, 72 Proc. Nat'L. ACAD. SCI. 2856 (1975).

112 Scott E. Page, The Difference: How the Power of Diversity Creates Better Groups, Firms, Schools, AND Societies (new ed. 2008).

113 See, e.g., Valerie Strauss, Taking on the Economics of Gender Inequity, WASH. Post, Dec. 3, 2007.

114 Graciela Chichilnisky, Sex and the Ivy League, in Reflections of EMINENT EConomists 108 (Michael Szenberg \& Lall Ramrattan eds., 2004). 
recently been reporting facing micro-aggressions, sexism, and sexual harassment. ${ }^{115}$ Professor Iris Bohnet, who is a behavioral economist, director of the women and public policy program, and co-chair of the behavioral insights group at the Kennedy school of government, wrote a book about how to de-bias organizations instead of individuals through behavioral design. ${ }^{116}$

In his path-breaking Ph.D. thesis, Arrow proved there is no voting procedure that satisfies all of these desirable axioms: consensus, decisiveness, independence of irrelevant alternatives, and non-dictatorship. ${ }^{117}$ Arrow single-handedly created the modern fields of mathematical social choice theory ${ }^{118}$ and mathematical politics. ${ }^{119}$ Robert J. Aumann, a 2005 Nobel memorial prize in economic sciences recipient, ${ }^{120}$ believes Arrow's impossibility theorem "fundamentally altered economic and political theory and practice." ${ }^{121}$ Eric Maskin, who is one of Arrow's former applied mathematics graduate students and a 2007 Nobel memorial prize in economic sciences recipient, ${ }^{122}$ and Amartya Sen, a 1998 Nobel memorial prize in economic sciences recipient, ${ }^{123}$ each presented an invited lecture at Columbia University about Arrow's famed impossibility theorem. ${ }^{124}$ Arrow applied a discrete, finite, and set-theoretic framework to prove his impossibility theorem. Chichilnisky's novel approach to social choice problems was continuous and applied topological methods, which generated some controversy in terms how to appropriately express formally some central claims in social choice theory. ${ }^{125}$

Law professor Leo Katz argues that many legal foundational conundrums, puzzles, and perversities arise from a constellation of related logical difficulties associated with legal doctrines involving multi-criterial decision-making. ${ }^{126} \mathrm{Katz}$ explains how many legal paradoxes are legal counterparts of the well-known voting paradoxes described in Arrow's impossibility theorem, Sen's libertarian

115 Nashwa Bawab, College Women in Tech: We're Encountering Sexism Already, USA ToDAY, Aug. 1, 2017, 10:12 pm EDT, http://college.usatoday.com/2017/08/01/collegewomen-in-tech-were-encountering-sexism-already/.

116 Iris Bohnet, What Works: GeNDER EQuity by Design (2016).

117 Kenneth J. Arrow, Social Choice and Individual Values (2012 reprint of 1951 ed.).

118 See, e.g., Donald G. SaAri, Basic Geometry of Voting (2013), Donald G. SaAri, Disposing Dictators, Demystifying Voting Paradoxes: Social Choice Analysis (2007); Donald G. Saari, Chaotic Elections! A Mathematician Looks at Voting (2001); Donald G. SaAri, Decisions and Elections: Explaining the Unexpected (2001).

119 Alan D. Taylor \& Allison M. Pacelli, Mathematics and Politics: Strategy, Voting, Power, AND Proof (2d ed., 2008).

120 Robert J. Aumann, War and Peace, 103 Proc. Nat'L. Acad. Sci. 17075 (2006).

121 Associated Press, Nobel-Winning Economist Kenneth J. Arrow Dies at 95, Feb. 23, 2017, https://phys.org/news/2017-02-nobel-winning-economist-kenneth-arrow-dies.html.

122 Eric S. Maskin, Mechanism Design: How to Implement Social Goals, 98 Am. Econ. Rev. 567 (2008).

123 Amartya Sen, The Possibility of Social Choice, 8998 Am. Econ. Rev. 349 (1999).

124 Eric Maskin \& Amartya Sen, The Arrow Impossibility Theorem (2014).

125 Nick Baigent \& Peter Huang, Topological Social Choice: A Reply to Le Breton and Uriate, 7 Soc. Choice \& Welfare 141 (1990).

126 Leo Katz, Why the LaW is So Perverse (2011). See also Leo Katz \& Alvaro Sandroni, The Inevitability and Ubiquity of Cycling in All Feasible Legal Regimes: A Formal Proof, 46 J. Legal Stud. 237 (2017). 
paradox, ${ }^{127}$ Chichilniky's theorem, and the Gibbard-Satterthwaite theorem. ${ }^{128}$ I critically analyze Katz's view that logical unavoidability of legal loopholes implies exploiting loopholes is ethically acceptable. ${ }^{129}$

In the summer between my second and third years of graduate school, I followed Arrow to Stanford, where he went annually to participate in a series of seminars and workshops at the Institute for Mathematical Studies in the Social Sciences (I.M.S.S.S.) and later its successor, the Stanford Institute for Theoretical Economics (S.I.T.E.). Talks occurred weekly on Tuesdays and Thursdays. Presenters distributed their unpublished working papers beforehand. There were lively debates, discussions, and exchanges before, during, and after each talk. All the papers concerned some novel aspect of mathematical economics. Sometimes there were additional talks about game theory on Wednesdays. Presenters ranged from past and future Nobel memorial prize in economic sciences recipients, including the famed game theorist Aumann; Roger Myerson, another of Arrow's former applied mathematics graduate students and a 2007 Nobel memorial prize in economic sciences recipient; ${ }^{130}$ and Jean Tirole, a 2014 Nobel memorial prize in economic sciences recipient. ${ }^{131}$ It was exhilarating to converse with and learn from some amazing intellectual giants in mathematical economics. I also immediately fell in love with the climate, collegiality, camaraderie, community, and culture at Stanford's I.M.S.S.S. and later S.I.T.E. Among economists in academia, there is a well-established traditional hierarchy of social status under which mathematical economists are the most-respected among and revered of economists primarily because of their rare mathematical prowess. ${ }^{132}$ Most economists do empirical research because of the rare level of mathematics required to do economic theory, let alone mathematical economics.

I vividly remember many thought-provoking and stimulating lunches, while sitting outside Stanford's coffee house or Tressider Memorial Union. One was with Arrow and D. John Roberts, a Stanford graduate school of business (GSB) management professor. We discussed professors who published just one very wellreceived article and subsequently only published less well-received articles or never published anything else. These folks are the scholarly equivalent of music performers who are known as one-hit wonders. We mused over whether they were better off than others who never published any very well-received articles.

We also spoke about how Redwood City, California, approximately five miles northwest of Stanford University, has a motto: "Climate Best by Government Test," which refers to it being a location the United States and German governments determined through climate surveys and meteorological data to have one of the

Amartya Sen, The Impossibility of a Paretian Liberal, 78 J. PoL. Econ. 152 (1970).

128 Allan Gibbard, Manipulation of Voting Schemes: A General Result, 41 Econometrica 587 (1973); Mark Allen Satterthwaite, Strategy-Proofness and Arrow's Conditions: Existence and Correspondence Theorems for Voting Procedures and Social Welfare Functions, 10 J. ECON. THEORY 187 (1975).

129 Peter H. Huang, Book Review of Leo Katz Why the Law is So Perverse, 63 J. LegaL EDUc. 131, 134, 137-48 (2013).

130 Roger Myerson, Perspectives on Mechanism Design in Economic Theory, 98 Aм. Econ. REv. 586 (2008).

131 Jean Tirole, Market Failures and Public Policy, 105 Am. Econ. Rev. 1665 (2015).

132 Axel Leijonhufvud, Life Among the Econ, 11 West. ECON. J. 327, 333-34 (1973). 
world's three best climates, with the other two being the Canary Islands and the Mediterranean Coast of North Africa. ${ }^{133}$ The motto best climate raises the question of what best means in the context of climate. People have diverse preferences about climate or weather, which consists of multiple dimensions, such as humidity, precipitation, and temperature. Temperature is a random variable and temperature over time is a stochastic process. Some people prefer to experience distinct seasons, meaning they prefer positive variance in precipitation and temperatures. Others prefer a high mean and low variance in temperatures.

In a fun lunch with Aumann, we spoke at length about many topics, including his article about whether two people can agree to disagree, ${ }^{134}$ his chapter about what game is trying to accomplish, ${ }^{135}$ conditions for the convergence of players' probability beliefs over others' strategy choices in normal form games, and viewing dating as attempting to solve for an equilibrium in an asymmetric information twoperson extensive form game! I enjoyed many delightful, humorous, and spontaneous conversations with Aumann about his path-breaking research in repeated game theory, ${ }^{136}$ correlated equilibria, ${ }^{137}$ and common knowledge. ${ }^{138}$ Aumann had a smile and laughter that were irresistibly contagious.

In addition to lunches, there were many engaging and fun conversations about academia and mathematical economics in corridors, elevators, offices, and outdoors. I remember having numerous conversations with Paul Milgrom, ${ }^{139}$ well-known for his research in designing optimal auctions for multiple unique but related items, ${ }^{140}$ and with Bob Wilson, ${ }^{141}$ designing the initial auction for sales of radio spectrum licenses in the United States. We spoke about classic film noirs, his article about how to formally represent favorable and unfavorable news in analytical models of information economics, ${ }^{142}$ and the wide readership of the I.M.S.S.S. technical report series.

During my third year of graduate school, Arrow decided to leave Harvard and return to Stanford. I followed Arrow to Stanford with the official designations of traveling scholar at Harvard and visiting scholar at Stanford. I underwent a delayed adolescence at Stanford, while being a teaching assistant for a section of intermediate microeconomics. I learned to ride a bicycle, drive a car, play organized 6-person volleyball (unfortunately on asphalt courts instead of sand or even grass),

133 Quora, What does the "climate best by government test" sign at the Redwood City Caltrain station mean? https://www.quora.com/What-does-the-climate-best-bygovernment-test-sign-at-the-Redwood-City-Caltrain-station-mean.

134 Robert J. Aumann, Agreeing to Disagree, 4 AnN. StAT. 1236 (1976).

135 Robert J. Aumann, What is Game Theory Trying to Accomplish? in FronTIERs oF ECONOMics 28 (Kenneth J. Arrow \& Seppo Honkapohja eds., 1985).

136 Robert J. Aumann, Michael Maschler, \& Richard Stearns, Repeated Games with INCOMPLETE INFORMATION (1985).

137 Robert J. Aumann, Subjectivity and Correlation in Randomized Strategies, 1 J. Mathematical Econ. 67 (1974).

138 Aumann, supra note 134.

139 Paul Milgrom Personal Website, http://www.milgrom.net/.

140 Paul Milgrom, Discovering Prices: Auction Design in Markets with Complex CONSTRAInTs (2017).

141 Robert Wilson, Stanford Graduate School of Business, https://faculty-gsb.stanford.edu/ wilson/index.html.

142 Paul R. Milgrom, Good News and Bad News: Representation Theorems and Applications, 12 BeLl J. ECON. 380 (1981). 
date Stanford co-eds, and understand the pros and cons of running different plays and sets in a 6-2 versus 5-1 offensive system in intercollegiate women's volleyball.

I attended every home and away match the Stanford women's volleyball team played one season. A setter/outside hitter on that team, Jody Freeman, would often do one-handed push-ups on the sidelines during warm-ups before matches to intimidate and psych out opposing teams. Jody today is the Archibald Cox professor at Harvard law school, the founding director of its environmental law and policy program, a leading environmental law and administrative law and regulation scholar, and independent outside director at ConocoPhillips, serving on its public policy and compensation committees. ${ }^{143}$ Jody co-edited an accessible, scholarly treatise about American law and climate change, ${ }^{144}$ in which she also co-authored a chapter about possible innovative U.S. legal policies to help mitigate the damages from global climate change. ${ }^{145}$

I sat in on and was a grader for the year-long graduate industrial organization course Bill Rogerson, ${ }^{146}$ a then new Stanford economics assistant professor with a $\mathrm{Ph} . \mathrm{D}$. from Cal Tech, taught. We also shared meals and hung out together socially. Rogerson is now the Harold and Virginia Anderson professor of economics at Northwestern University and currently serves as economics department chair, co-director of the center for the study of industrial organization, director of the program in mathematical methods in the social sciences, and research director of the program on competition, antitrust and regulation at the Searle center on law, regulation and economic growth. ${ }^{147}$

I also sat in on several graduate courses at Stanford GSB about game theory, multi-person decision theory, information economics, public finance and taxation, and topics in game theory. A new assistant professor of decision sciences, Anat Admati, ${ }^{148}$ taught one such course. Admati has become a refreshing strong advocate of reforming bank capital regulation and recently published a skeptical view of financialized corporate governance. ${ }^{149}$ Admati and Hellwig ${ }^{150}$ coauthored the book, The Bankers' New Clothes: What's Wrong with Banking and What to Do about $I t{ }^{151} \mathrm{I}$ was a grader for two sections of the first-year core M.B.A. microeconomics course, one taught by Margaret Bray, ${ }^{152}$ and another taught by William F. Sharpe,

143 Harvard Law School Faculty Profiles, Jody Freeman, http://hls.harvard.edu/faculty/ directory/10285/Freeman; Harvard Law School Faculty, Professor Jody Freeman, http:// www.law.harvard.edu/faculty/freeman/.

144 Global Climate Change and U.S. Law (Michael Gerrard \& Jody Freeman eds., 2d ed. 2015).

145 Id. at 735.

146 William Rogerson Northwestern University Economics Department Home Page, http:// faculty.wcas.northwestern.edu/ wpr603/.

147 http://faculty.wcas.northwestern.edu/ wpr603/bio.pdf.

148 Anat R. Admati, Stanford Graduate School of Business, https://www.gsb.stanford.edu/ faculty-research/faculty/anat-r-admati.

149 Anat R. Admati, A Skeptical View of Financialized Corporate Governance, J. Econ. Perspectives, Summer 2017, at 131.

150 Hellwig, supra note 70.

151 Anat R. Admati \& Martin Hellwig, The Bankers' New Clothes: What's Wrong With BANKING AND What to Do ABOUt IT (2013); http://bankersnewclothes.com/.

152 London School of Economics, Dr. Margaret Bray Faculty Page, http://www.lse.ac.uk/ economics/people/facultyPages/MargaretBray.aspx. 
famous for his role in developing the canonical financial capital asset pricing model, and a 1990 recipient of the Nobel memorial prize in economic sciences. ${ }^{153}$

\section{ECONOMiCS or FinanCe Faculty at Multiple SCHOols}

I was an economics instructor at Cañada Community College, assistant professor at Tulane University, and visiting assistant professor at the University of Iowa, Southern Methodist University, the University of California, Berkeley, the University of California, Los Angeles, the University of Southern California, and Stanford University. I have taught a diverse range of undergraduate and graduate economics courses: microeconomics principles, macroeconomics principles, intermediate microeconomics, industrial organization, public finance, mathematical economics, microeconomic theory, advanced microeconomic theory; law and economics, modern welfare economics, economics of the firm, organization economics, speculative markets, game theory and economic applications, and optimization and economic analysis. I have also taught these two courses in the finance department of the A.B. Freeman business school at Tulane University: investments, a standard required undergraduate business course, ${ }^{154}$ and options and futures markets, a standard elective second year M.B.A. course. ${ }^{155}$

At the start of my second semester at Tulane, on the first day of class, I was going over my section of the principles of microeconomics course syllabus in class when a student raised her hand and asked if I knew what Mardi Gras was. I replied I was familiar with the concept. She said Mardi Gras is not a concept, it's a way of life. I said everything is a concept and asked if she would care to elaborate about Mardi Gras because she seemed to be very familiar with the Mardi Gras concept. She said that Mardi Gras is an opportunity to go out, drink alcohol, party, and have a fun time. I thought and did not say how does that differ from many other evenings in her undergraduate experience. I decided to ask why she asked if I was familiar with Mardi Gras. She answered because on the course syllabus, there is a reading assignment for Mardi Gras and a related homework assignment due on the next day. She asked if this was my initial year of teaching at Tulane. I stated yes and she as a freshman said that I would come to learn to have more realistic expectations about what students do on Mardi Gras and how many students attend classes the day after Mardi Gras. She was quite right. I learned that year to never again assign any reading for Mardi Gras nor have homework due on the day after Mardi Gras. Both would be quite unrealistic for most students.

During the course review session for a section of microeconomics principles I taught at Tulane, a student asked if a particular topic we were discussing was important. I thought and did not say sarcastically the topic was unimportant and I was just wasting their time and mine. I instead asked that student what she meant by important, for her soul, the final examination, or life? She replied of course for

153 William F. Sharpe, Capital Asset Prices with and without Negative Holdings, 46 J. FIN. 489 (1991) (Nobel lecture).

154 This course covered modern portfolio theory, capital asset pricing model, arbitrage pricing theory, bonds, stocks, mutual funds, and collectibles.

155 This course covered the markets, pricing, and valuation of derivative securities and contingent claims. 
the purposes of passing the final examination and the course. I replied there are more important things than any one final examination grade and any one course grade. She said while that was true in the grand scheme of things, her immediate focus had to be on the final examination grade. I tried to convince her that learning to appreciate the benefits and costs of seeing the world from a microeconomics point of view likely would have a longer-term impact on her life than her final examination grade. I am not sure if she was convinced. As Sean Covey wrote in The 7 Habits of Highly Effective Teens, "grades are important, learning is more important, so make sure you don't forget why you're in school to begin with."156

After teaching three years at Tulane, I passed a mid-tenure review and received an academic year-long sabbatical, during the fall of which I was a visiting scholar at Stanford law school and a visiting assistant professor in economics at the University of California, Berkeley. I taught a section of intermediate microeconomics with about ninety students. One of the students asked me whether I thought it was a good idea to apply to law school. I asked her if she wanted to attend law school. She answered that her dad wanted her to attend law school. I asked her again if she wanted to attend law school. She answered that her boyfriend wanted her to attend law school. I asked her once more if she wanted to attend law school. She answered that she was not sure that she wanted to attend law school. I told her that she did very well on the midterm and could apply to attend business school, public policy school, or graduate school in economics. She ended up applying to law school and choosing between attending law at Stanford and the University of California, Berkeley's Boalt law school.

Terrance Odean was another student in that course. Terry always sat in the front row of class. It was only last May during the 2016 Boulder summer conference on consumer financial decision-making ${ }^{157}$ that I learned Terry sat in the front row because Terry felt I spoke too fast and Terry wanted to catch what I was saying. Terry was a senior pursuing a bachelor of arts degree in statistics. Terry was a bit older than me and had returned to college at the University of California, Berkeley at the age of 37 . Terry asked me to write a recommendation letter in support of his application to pursue a Ph.D. in finance at only the University of California, Berkeley. I suggested Terry also apply to Stanford, Harvard, etc. in the spirit of portfolio diversification. Terry said that for personal family reasons, he was only applying to the University of California, Berkeley. Another of Terry's recommendation letter writers was Daniel Kahneman, a 2002 economics Nobel laureate. ${ }^{158}$ Terry was accepted by the finance Ph.D. program at the University of California, Berkeley.

Terry is now a well-known behavioral financial economist at the Rudd Family Foundation Professor and Chair of the Finance Group at the Haas School of Business, University of California, Berkeley. ${ }^{159}$ Terry was a former director of UC Berkeley's Xlab, an experimental social science laboratory. Terry also co-authored a clever and famous article utilizing account data for over 35,000 households

156 Sean Covey, The 7 Habits of Highly Effective Teens 220 (2014).

157 http://www.colorado.edu/business/sites/default/files/attached-files/boulder_summer_ conference_program_2016_corrected_proof.pdf.

158 Daniel Kahneman, $\bar{M}$ aps of Bounded Rationality, 93 Am. Econ. Rev. 1449 (2003) (Nobel lecture).

159 Terrance Odean Personal Homepage, http://faculty.haas.berkeley.edu/odean/. 
from a large discount brokerage to analyze the common stock investments of men and women from February 1991 through January 1997 and found men trading 45 percent more than women and earning annual risk-adjusted net returns 1.4 percent less than women earn; the differences are more pronounced between single men and single women with single men trading 67 percent more than single women and earning annual risk-adjusted net returns that are 2.3 percent less than single women earn. ${ }^{160}$ Terry's current research empirically shows that: (1) women Chartered Financial Analyst (CFA) members are less conformity and tradition-oriented and more achievement-oriented than both men CFA members and women in the population at large, ${ }^{161}(2)$ the mathematics gender gap predicts the percentage of women investment professionals across countries and across states, ${ }^{162}$ and (3) among CFA Institute members, women are more likely to have a STEM parent (particularly a STEM mother) than men; STEM mothers increase the rate that daughters become CFA Institute members by $48 \%$ more than sons; and STEM fathers increase the rate that daughters become CFA Institute members by $29 \%$ more than sons. ${ }^{163}$

Terry also created a series of user-friendly instructional personal finance videos on YouTube. ${ }^{164}$ I have assigned his terrific videos to law students in these two courses: (1) economic analysis of law, and (2) legal ethics and professionalism: business law issues. In the course on law and economics, I explain to students that finance is economics over time and under risk. I also teach students that having some financial literacy is desirable. In the course on legal ethics and professionalism, I explain to students that lacking financial literacy can lead to unethical and/or unprofessional behavior. In both courses, I teach students to understand the nonlinearity of compound interest and the importance of living frugally. Appreciating how compound interest works helps convince students to save as much as they can as soon as they can. ${ }^{165}$ I explain that lawyers have to be ready to be fired or quit instead of engage in unethical or unprofessional behavior. I then explain the way to be prepared to resign or be terminated is to live well below your means. I remind students of the difference between want and need. Law students come to appreciate why and understand how practicing financial mindfulness and retirement planning enables them be able to say no thank you to becoming entangled in unethical career-ending professional disasters. Discussing how mindfulness and financial decision-making are interdependent provides a pragmatic example of how mental health and financial health can affect each

160 Brad M. Barber \& Terrance Odean, Boys will be Boys: Gender, Overconfidence, and Common Stock Investment, 116 QuART. J. Econ. 261 (2001).

161 Renée B. Adams, Brad M. Barber \& Terrance Odean, Family, Values, and Women in Finance, Mar. 8, 2017, https://papers.ssrn.com/sol3/papers.cfm?abstract_id=2827952.

162 Renée B. Adams, Brad M. Barber \& Terrance Odean, The Math Gender Gap and Women's Career Outcomes, Mar. 16, 2017, https://papers.ssrn.com/sol3/papers. cfm?abstract id $=2933241$.

163 Renée B. Adams, Brad M. Barber \& Terrance Odean, STEM Parents and Women in Finance, July 18, 2017, https://papers.ssrn.com/sol3/papers.cfm?abstract_id=2975898.

$164 \mathrm{https} / / / \mathrm{www}$. youtube.com/user/PR67895/playlists.

165 Peter H. Huang, Achieving American Retirement Prosperity by Changing Americans' Thinking About Retirement, 22 Stan. J.L., Bus. \& Fin. 189-259 (2017). 
other. ${ }^{166} \mathrm{I}$ also recommend Terry's videos to family and friends as ways to learn important financial ideas and concepts in an engaging and fun way.

\section{STANFORD UNIVERSITY 2L-3L AND UNIVERSITY OF CHICAGo $1 L$}

I earned a J.D. from Stanford law school (SLS) upon transferring after being a 1L at the University of Chicago ( $\mathrm{U}$ of $\mathrm{C}$ ) law school. I have already written at some length elsewhere about being an anxious, stressed fish-out-of-water $1 \mathrm{~L}$ at the $\mathrm{U}$ of $\mathrm{C},{ }^{167}$ being a calmer, happier more-at-home $2 \mathrm{~L}$ and $3 \mathrm{~L}$ at SLS, ${ }^{168}$ being on both sides of the entry level law faculty market, ${ }^{169}$ and teaching in several vastly different law school cultures, ranging from quite collegial at the University of Southern California to southern at the University of Virginia to dysfunctional at several other places. ${ }^{170}$

Some colleagues have asked me whether and how being a $2 \mathrm{~L}$ and $3 \mathrm{~L}$ at SLS differed from being a $1 \mathrm{~L}$ at $\mathrm{U}$ of $\mathrm{C}$ law school. The answer is the difference is like that between temperate, cheerful, blue-sky, and sunny Palo Alto, California versus cold, gloomy, gray, and overcast Hyde Park, Illinois. The student cultures at SLS and $\mathrm{U}$ of $\mathrm{C}$ are genuinely like day and night respectively. At the $\mathrm{U}$ of $\mathrm{C}$ law school, most students humble-bragged they studied weekends, even if they did not. At SLS, most students humble-bragged they did not study weekends, even if they did. At the U of C law school, most professors called students Mr. or Ms. and the student's last name. At SLS, most professors called students by the student's first name. At the $\mathrm{U}$ of $\mathrm{C}$ law school, most professors used the cold-calling inquisitorial Socratic method, some effectively and some not. At SLS, professors used various teaching methods, including a gentler and kinder form of Socratic dialogue without cold calling and with students on assigned panels, voluntary discussion, and/or lecture. At the $\mathrm{U}$ of $\mathrm{C}$ law school, most professors dressed in suits as their teaching costumes, even women. At SLS, most professors dressed in what the SLS registrar called the faculty's casual gardening clothes (because they were fertilizing their students' minds). At the U of C law school, many students and faculty would habitually and routinely apply elementary microeconomics to analyze law, even if they did it often simplistically and sometimes incorrectly. At SLS, many students and faculty criticized applying elementary microeconomics to analyze legal rules and institutions, even if they did it often simplistically and sometimes incorrectly.

I took many seminars at SLS and for each one, wrote an independent research paper, some of which formed the foundation of a law review article published after law school. For example, I learned basic human biology and genetics in a seminar course titled Advanced Health Law, covering the ethical, legal, and social implications arising from advances in our knowledge of human genetics. ${ }^{171} \mathrm{My}$

166 Peter Dunn, Pete the Planner: How Mental Health Impacts Financial Health? 10 USA ToDAY (Aug. 26, 2017, 7:00 AM), https://usat.ly/2xBs6qx.

167 Huang, supra note 1, at 328-31.

168 Id. at 332-33.

169 Id. at 334-35.

170 Id. at $335-45$.

171 This course covered such topics as consequences of genetics for human reproduction, ethics of genomic biobanks for research, forensic uses of genetics, genetic enhancement, 
independent research paper, Herd Behavior in Designer Genes, was invited to be published in a symposium issue of the Wake Forest Law Review. ${ }^{172}$ My law and economics seminar course paper, A New Options Theory for Risk Multipliers of Attorneys' Fees in Federal Civil Rights Litigation, became my academic job market paper and was published in the New York University Law Review. ${ }^{173} \mathrm{My}$ senior thesis, The Unexpected Value of Litigation: A Real Options Perspective, was published nine years later in the Stanford Law Review. ${ }^{174}$

I took a course titled Decision Analysis ${ }^{175}$ in conjunction with applying and becoming a Stanford Center on Conflict and Negotiation (S.C.C.N.) fellow in the spring of $1996 .{ }^{176}$ A team of professors taught the course. That team included Amos Tversky, a cognitive psychologist whose joint research with another psychologist Daniel Kahneman formed the foundations of behavioral law and economics. ${ }^{177}$ Michael Lewis, the author of Moneyball, wrote a book about the unique collaboration between Tversky and Kahneman. ${ }^{178}$ Kahneman was a recipient of the 2002 Nobel memorial prize in economic sciences ${ }^{179}$ "for having integrated insights from psychological research into economic science, especially concerning human judgment and decision-making under uncertainty." ${ }^{180}$ A central insight of Tversky and Kahneman's research is that people often make different choices when mathematically equivalent choices are presented differently. ${ }^{181}$ An example of this preference inconsistency is when people have different emotional responses to and make different choices about alternatives depending on if those options are presented a negative frame such as mortality rates or a positive frame such as survival rates. By definition, the mortality rate of any alternative is one minus the survival rate of that same alternative. A perhaps apocryphal story is that when Amos Tversky learned about his diagnosis of metastatic melanoma, Amos Tversky asked the physician to speak in terms of survival rates to Barbara Tversky, Amos' wife and colleague in the Stanford psychology department. The physician agreed to do so and then spoke to Barbara Tversky in terms of mortality rates.

genetic testing, genome editing, genome synthesis, and widespread whole genome sequencing.

172 Peter H. Huang, Herd Behavior in Designer Genes, 34 Wake Forest L. Rev. 639 (1999).

173 Peter H. Huang, A New Options Theory for Risk Multipliers of Attorneys' Fees in Federal Civil Rights Litigation, 73 N.Y.U. L. Rev. 1943 (1998).

174 Joseph A. Grundfest \& Peter H. Huang, The Unexpected Value of Litigation: A Real Options Perspective, 58 Stan. L. Rev. 1267 (2006).

175 This one-credit pass fail course was cross-listed in several other departments and required students to attend weekly presentations about decision-making by professors from other law schools, economics departments, and psychology departments.

176 S.C.C.N. fellows met with the speakers and shared conversation over dinner.

177 Paul Brest, Amos Tversky's Contributions to Legal Scholarship: Remarks at the BDRM Session in Honor of Amos Tversky, June 16, 2006, 1 Judgment \& DeCision Making 174 (2006).

178 Michael Lewis, The Undoing Project: A Friendship That Changed Our Minds (2016).

179 Kahneman, supra note 158.

180 The Sveriges Riksbank Prize in Economic Sciences in Memory of Alfred Nobel 2002, The Official Web Site of the Nobel Prize, http://www.nobelprize.org/nobel_prizes/economicsciences/laureates/2002/kahneman-facts.html.

181 Daniel Kahneman \& Amos Tversky, Prospect Theory, 47 Econometrica 263 (1979). 


\section{E. LaW Faculty at Multiple SChools}

After the first law school class I taught, a University of Pennsylvania law student came up and asked if this was the first time I was teaching securities regulation. I answered yes and he replied that he preferred to take a course from a professor who was not teaching it for the first time. I said that I understood and respected how he felt. I thought and did not say that I preferred to teach students who were not taking a course for the first time. My point in recounting this interaction is to draw attention to how students in any course are heterogeneous in their background, motivation, preparation, and tenacity. Students have the options to be more or less hard-working, motivated, and prepared. Teachers must accept a reality in which not all students will be hard-working, motivated, and prepared to learn. Teachers can and should engage students by making clear why the course is relevant for students and how the course can make a positive difference in their lives.

Karl Schellscheidt was a student in my section of securities regulation in his and my second year at the University of Pennsylvania law school. We shared a meal and/or ice cream together every now and then in the food court near the law school in the semesters after Karl took the course. His eldest daughter was born right before he started law school, his second was born right after his second year first semester exams, and his third was born right after he took the bar exam. Karl was a corporate lawyer for Dechert LLP for a couple of years.

Five years after Karl graduated, I saw Karl again in McCaffrey's Food Market in Princeton shopping center when I was a member of the Institute for Advanced Study School of Social Science during the 2005-2006 academic year, its psychology and economics themed year. We resumed our friendship and spoke about utilizing technology to democratize the delivery of education. Based on his over twenty-five years of teaching and private tutoring experience, Karl co-founded ePrep, Inc., a unique video-based online test prep study program that provides the benefits of expert private tutoring to its clients at an affordable cost. ${ }^{182}$ Karl is ePrep's president and chief executive officer. Before law school, Karl graduated from Princeton University with a bachelor's degree in civil engineering and from Seton Hall University with a master's degree in secondary education. Karl was an environmental science instructor for the office of continuing education at Rutgers University. Karl also taught, coached, and served as a dorm parent at the Hun School of Princeton.

I taught in the spring of my first year of teaching law school a firstyear perspectives elective in law and economics. I had taught versions of an undergraduate course in law and economics in the economics departments at Tulane University and the University of Southern California. Many of those students were pre-law majors in economics or political economy and all of the students had taken intermediate microeconomics. We covered a brief introductory paperback about law and economics ${ }^{183}$ and a more comprehensive textbook about law and economics that surveyed from an economic viewpoint the core first-year law subjects of property, torts, contracts, civil procedure, and criminal law. ${ }^{184}$ Law

82 ePrep, https://www.eprep.com/.

183 A. Mitchell Polinsky, An InTroduction to Law and Economics (4th ed. 2011).

184 Robert CoOter \& Thomas Ulen, LaW \& Economics (6th ed. 2011). 
students taking a law and economics course form a bimodal distribution in their knowledge of microeconomics. We covered elements of price theory, behavioral economics, and game theory.

Two law students in that course received a grade of A+ and made the University of Pennsylvania law review because of that. Both of those students took securities regulation from me in the fall of their and my second year at the University of Pennsylvania law school. One of them became a summer associate practicing securities in the New York City office of a so-called "white shoe" law firm. She jokingly asked me if I would be able to get her out of the University of Pennsylvania law school public interest requirement. I replied that I did not have the power and even if I did, she should do some public interest. She chose to teach law to local high school students and found it exhilarating. I asked if that experience changed her career plans. She replied that she had accepted an offer to be an associate in the New York City office of a so-called "white shoe" law firm to be focusing on securities, mergers and acquisitions, and private equity. She mentioned that she was tired of eating Kraft brand or even sometimes generic brands of macaroni and cheese. A couple of years later, when I attended the American law and economics association meetings held at NYU law school, we met for dinner. She ordered as her main course an entree of macaroni and cheese that cost forty-five dollars. She mentioned that if she is at work after six-o-clock, she can order dinner compliments of her law firm and if she is at work past nine-o-clock, she can order a limousine ride home compliments of her law firm. If she was a rational economic actor who learned law and economics well, then she would probably leave work after 9 p.m.

I have taught a diverse range of elective and required courses in law schools at the University of Pennsylvania, the University of Southern California, the University of Chicago, the University of Virginia, the University of Minnesota, and Yale University. I have taught these courses: business associations; business basics for lawyers; corporate finance; derivative securities and their regulation; economic analysis of law; financial decision-making; law and economics; law and human behavior; law, happiness, and neuroscience; law, happiness, and subjective well-being; law and popular culture; legal ethics and professionalism: business law issues; media, law and popular culture; neuroscience and law; securities regulation; securities litigation and enforcement; and torts. I was the inaugural Harold E. Kohn Chair professor at Temple University law school. I am currently a law professor and the inaugural DeMuth Chair of business law at the University of Colorado, Boulder.

When I was a member in the School of Social Science at the Institute for Advanced Study, some other members were surprised by my being a lawyer and former mathematical economist. An economic theorist stated that my introducing myself to him as a business law professor was misleading as it belied how much general equilibrium theory I knew and that I co-authored an article in the Journal of Mathematical Economics about existence of general equilibrium for a system of incomplete asset markets. ${ }^{185}$ Other members would sometimes ask me to provide free financial or legal advice. I declined after reminding them that price can be a signal of quality.

185 Peter H. Huang \& Ho-Mou Wu, Competitive Equilibrium of Incomplete Markets for Securities with Smooth Payoffs, 23 J. Mathematical Econ. 219 (1994). 
Two women behavioral law and economics scholars who each hold a J.D. and an economics Ph.D. asked me while I was a $1 \mathrm{~L}$ whether I found being a law student or undergraduate mathematics major or graduate student in applied mathematics taking graduate economics courses to be more challenging or difficult. I told both of them such a comparison is like that between apples and oranges. That being said, I also told them that law school was often pedantic and unintellectual, while economics and mathematics were fun. Additionally, there is an about one order of magnitude difference between the couple of hundred first-year students in an entering class of a top law school program compared to about thirty first-year students in an entering class of a top economics graduate program. That difference reflects both applicant preferences and program selectivity. That difference also is associated with differences in student competition and culture. Graduate economics courses have $\mathrm{Ph} . \mathrm{D}$. teaching assistants running weekly sections and grading written homework assignments and midterms. Law school courses provide no such teaching support nor regular feedback to students.

I offered the above personal higher educational history to provide some background and context about my unique perspectives towards, and interests in, improving legal education. I learned many lessons from my unique experiences in higher education. For example, while a $1 \mathrm{~L}$, I paid close attention to how my law professors taught in addition to what they taught. There was very high variance across law professors in pedagogical efficiency and proficiency of Socratic dialogue. When I was an entry-level law faculty candidate, a senior non-business law professor asked me during an office interview if I would teach securities regulation using the tried and true method of Socratic instruction. I answered I would teach securities regulation the same way that it was taught to me by former S.E.C. Commissioner Joe Grundfest, namely using a lecture format. The senior non-business law professor leading the interview disagreed vehemently with not using the Socratic method and said Socratic dialogue is the only way to teach law students how to think for themselves. I chose not to ask this professor if he had any empirical data or evidence to support his assertion. I did not get an offer to join the faculty of that professor's law school.

I have learned as a teacher to meet students as they are and where they are. Teachers may prefer their students to be different people or to know less or more than they do. I also learned that it helps most students to not "hide the ball" in teaching. Most students appreciate having the course learning objectives and the method(s) of learning assessment explicitly stated (and emphasized) on their course syllabus. The method(s) of learning assessment should measure the student achievement of the course learning objectives. If there is a mismatch, then one or both must change to result in a match. The course assessment method(s) will dictate what students choose to spend their attention and time learning. The final examination or whatever is the course assessment method usually is the proverbial tail that wags the dog. Teachers are role models and sources of emotional contagion. If a teacher is curious, kind, and passionate, students are more likely to also be curious, kind, and passionate. Finally, I learned that a law school's leadership can matter a great deal, both positively and negatively. A law school dean can demoralize, dishearten, and undermine a law school's faculty, students, and staff by running a law school with a lack of ethics, lack of leadership, lack of accountability, secrecy, and top-down micro-management. A law school dean can instead encourage, hearten, and inspire a law school's faculty, students, and staff by running a law school with accountability, confident leadership, ethical leadership, participatory 
decision-making, and transparency. Leadership can make a big difference in the daily lived experiences of a law school's faculty, students, and staff. I co-authored an article applying psychological game theory to demonstrate the importance of organizational leaders being ethical leaders and role models to avoid corrupt cultures from developing and taking over an organization. ${ }^{186}$

\section{Why Teach Law Students About Happiness And MINDFULNESS?}

Law schools do not operate in vacuums. Law schools operate in markets or more accurately, quasi-markets, that is market-like settings. The J.D. degree has complements (joint degrees and L.L.M. degrees) and substitutes (M.L.S. degrees). There has always been and is now more than ever intense competition among law schools for applicants, attention, students, professors, deans, donations, prestige, and media coverage. There are sub-quasi-markets indexed by geographical regions, legal specialty areas, and U.S. News \& World Report ranking cohorts. Many law school stakeholders believe their law school deserves to be ranked higher than it is and has as its real peers higher-ranked law schools. Such inaccurate and self-serving beliefs are often delusional, inspirational, or wishful thinking. The law school quasi-market has barriers to entry, informational asymmetries, and reputational stickiness. Yale has been and is likely to be stuck as the U.S. News \& World Report number one ranked law school, even if wanted to have the ranking of zero or a negative number!

There is deliberate and innate opaqueness about law school quality, imperfect self-regulation, and conflicted self-governance. Law school stakeholders are heterogeneous and may even have conflicting objectives based on differences in beliefs, philosophies, preferences, risk attitudes, time horizons, and values. Law schools operate in quasi-markets likely to have industrial organizational structures that are problematic from the viewpoints of distributional equity and economic efficiency.

There are long-standing differences among law school admits, applicants, students, faculties, and deans in attitudes towards lack of diversity by ethnicity, gender, and socio-economic class. Policies about increasing diversity are often contested and contentious among faculty. Based on interviews between 2009 and 2011 at two law schools of one hundred and six law students, non-participant observations of panethnic student groups, and analysis of email list correspondence, sociology professor Yung-Yi Diana Pan analyzes how systemic inequalities are generated and sustained in law schools, racialization happens with professional socialization, panethnic students navigate their gender, identities, and race in an institutional context, how lived experiences of panethnic students influence their student organization association choices and career paths, and race operates in law schools for students of color and in white students' minds. ${ }^{187}$

186 Peter H. Huang \& Ho-Mou Wu, More Order Without More Law: A Theory of Social Norms and Organizational Cultures, 10 J.L. ECON. \& OrG. 390 (1994).

187 See, e.g., Yung-Yi Diana Pan, Incidental Racialization: Performative Assimilation IN LAW SCHOOL (2017). 
A law school can seek many objectives, include maximizing one of these variables: the law school's annual ranking according to U.S. News \& World Report, alumni engagement and involvement, applications, assessments by and reputation among lawyers and judges, bar passage rate of first-time test takers, number of law school graduates employed at graduation, number of law school graduates employed after ten months, enrollment, faculty's research reputation, peer assessment, selectivity, public perceptions and profile, students' L.S.A.T. scores (25th-75th percentile), and students' undergraduate G.P.A.s (25th-75th percentile). Some aspirations that many law schools do not seem to pursue are to become places and spaces that are happier, more diverse, more inclusive, more quantitative, and more welcoming.

Part II of this Article analyzes why teaching law students about happiness and mindfulness is a worthy goal. First, this part of the Article discusses law student discontent. Second, this part of the Article discusses what motivates law school applicants, students, alumni, and faculty. Third, this part of the Article discusses what motivates clients of law school graduates. Fourth, this part of the Article discusses how unhappy law students become unhappy lawyers. Fifth, this part of the Article discusses what motivates law professors.

\section{A. LAW Student Discontent, UnHAPPINESS, AND SUFFering}

A 2014 cross-sectional survey of law students at fifteen law schools found that about "one-quarter to one-third of respondents reported frequent binge drinking or misuse of drugs, and/or reported mental health challenges. Moreover, the results indicated that significant majorities of those law students most in need of help are reluctant to seek it." 188 At Yale, $70 \%$ of the law students surveyed (206 students in a sample of 296 students) admitted suffering from some type of mental health issues. ${ }^{189}$

Although many other professionals also face stress, as Yvette Hourigan, director of the Kentucky Lawyer Assistance Program, cogently pointed out:

Being a physician has stress. However, when the surgeon goes into the surgical suite to perform his surgery, they don't send another physician in to try to kill the patient. You know, they're all on the same team trying to do one job. In the legal profession, adversity is the nature of our game. ${ }^{190}$

Lawyers are often financially rewarded for being hostile. Some clients will seek and hire the most aggressive, antagonistic, argumentative, intimidating, unpleasant, and unsympathetic jerk of a gladiator they can find to be their divorce or torts lawyer. Adversarial rules of civil and criminal procedure incentivize, normalize, and reward a zero-sum, hypercompetitive, no-holds-barred, takeno-prisoners, winner-take-all mentality and mindset. An economically-minded

188 Organ, Jaffee, \& Bender, supra note 23, at 116.

189 Yale Law School Mental Health Alliance, Falling Through the Cracks: A Report on Mental Health at Yale Law School, Dec. 2014, https://law.yale.edu/system/files/falling through_the_cracks_120614.pdf.

190 Rosa Flores \& Rose Marie Arce, Why Are Lawyers Killing Themselves? Jan. 20, 2014, updated 2:42 pm ET, http://www.cnn.com/2014/01/19/us/lawyer-suicides/index.html 
observer might simply characterize the unhealthiness of law practice and law school as just additional costs of being a lawyer and law student, albeit emotional health, mental health and physical health costs that are hard to perhaps measure, observe, quantify, and verify.

Legal education often implicitly and even sometimes explicitly trains and socializes law students to be amoral, if not immoral. ${ }^{191}$ It is by now quite wellknown that many law students come into law schools bright-eyed and bushy-tailed with intrinsic values to do good, help the vulnerable and underprivileged in our society, and make our world a better place. ${ }^{192}$ Yet, too many law students end up obsessing in law schools about extrinsic values of comparative worth, such as their class rank, grades, honors, and salary offers. ${ }^{193}$ Law school often alters law students in many truly fundamental ways, some that are very undesirable personally and societally. ${ }^{194}$ The displacement of intrinsic values by extrinsic values that happens to many law students reduces their subjective well-being, deep sense of meaning or purpose, and self-concordance. ${ }^{195}$ It should be unsurprising that emotionally impaired and mentally unhealthy law students graduate to become emotionally impaired and mentally unhealthy lawyers. ${ }^{196}$ Scott Fruehwald, a law professor, posted a blog titled Why Professional Identity Training is So Important, focusing on how the years in law school can be formative and transformative in helping law students develop healthy and sustainable professional identities. ${ }^{197}$ Part of the raison d'être of law school is to help law students grow into and become flourishing lawyers. John Tomer, an economist who was a founder and past president of the society for the advancement of behavioral economics, recently wrote about how neoclassical economics and behavioral economics are both missing the same ingredient, namely:

the conception of a human being as an individual who develops in many different ways along a sequence of stages, a maturational path. As wise thinkers through the ages have recognized, humans are capable of attaining a very high level of development, involving a full flourishing of

191 Peter H. Huang, How Improving Decision-Making and Mindfulness Can Improve Legal Ethics and Professionalism, 21 J.L. Bus. \& Eтнісs 35 (2015).

192 Lawrence S. Krieger, Institutional Denial About the Dark Side of Law School, and Fresh Empirical Guidance for Constructively Breaking the Silence, 52 J. LeGal Educ. 112 (2012).

193 Lawrence S. Krieger \& Kennon M. Sheldon, Does Legal Education Have Undermining Effects on Law Students? Evaluating Changes in Values, Motivation and Well Being, 22 BEHAV. SCI. \& L. 261 (2004).

194 Lawrence S. Krieger, Psychological Insights: Why Our Students and Graduates Suffer, and What We Might Do About It, 8 J. Assn. L. Writing Directors 259 (2002).

195 Kennon M. Sheldon \& Lawrence S. Krieger, Walking the Talk: Value Importance, Value Enactment, and Well-Being, 38 Motivation \& EMOTION 609 (2014).

196 Lawrence S. Krieger, Service Job Lawyers Are Happier than Money Job Lawyers, Despite their Lower Income, 9 J. Pos. Psychol. 52 (2014).

197 Scott Fruehwald, Why Professional Identity Training Is So Important, Legal Skills Prof Blog, July 18, 2017,

http://lawprofessors.typepad.com/legal_skills/2017/07/why-professional-identitytraining-is-so-important.html. See also Scott Fruehwald, Developing Your Professional IDENTity: Creating Your InNer LaWyer (2015). 
all their human capabilities in the broadest and highest sense over their life cycle. ${ }^{198}$

Supreme Court Justice William Rehnquist wrote an opinion about private securities fraud litigation in which he stated: "we deal with a judicial oak which has grown from little more than a legislative acorn." 199 This memorable phrase offers a compelling picture of change over time. Sometimes, such change is a positive growth as is the case of a little acorn growing into a huge oak tree. Other times, the change is a negative descent as is all too often the case with idealistic, compassionate, curious, empathetic, and socially concerned law students becoming arrogant, anxious, depressed, hostile, and jaded lawyers.

Empirical evidence finds that law schools do not select unhappy students. ${ }^{200}$ Yet within the first semester of law school, many students report feeling adrift, anxious, apathetic, cynical, dejected, disaffected, disheartened, disillusioned, dispirited, frustrated, irritable, isolated, jaded, lost, overwhelmed, overworked, stressed, unhappy, and withdrawn. Hopefully, this negative affect is neither desired nor intended by most law professors. As law professors, we should first and foremost heed the maxim to do no harm! ${ }^{201}$ We can and must do better affectively by our students than emotionally harming them. ${ }^{202}$

Perhaps due to path dependence and serendipity, more legal clinical faculty, legal writing faculty, and law school administrators than legal doctrinal faculty have teaching and research interests about law student and lawyer happiness. This is unfortunate because legal doctrinal faculty have the most power and status at law schools in comparison with legal clinical faculty, legal writing faculty, and non-decanal law school administrators. This neglect of law student and lawyer well-being is yet another of the many inequities, issues, and problems with the traditional, institutional, and illegitimate status hierarchy among American law school faculties. ${ }^{203}$

Psychology professor Kennon Sheldon and law professor Lawrence Krieger conducted longitudinal studies at two law schools and found that law students at both schools experienced significant and substantial erosion of well-being and psychological need satisfaction within the first year of law school. They summarize the state of research findings as of 2007 in the first paragraph of their article:

198 John F. Tomer, Smart Persons and Human Development: The Missing Ingredient in Behavioral Economics, in Handbook of Behavioural Economics and Smart Decision-Making: Rational Decision-Making with the Bounds of Reason 137-38 (Morris Altman ed., 2017).

199 Blue Chip Stamps v. Manor Drug Stores, 421 U.S. 723, 737 (1974).

200 Lawrence S. Krieger \& Kennon M. Sheldon, What Makes Lawyers Happy?: A DataDriven Prescription to Redefine Professional Success, 83 Geo. Wash. L. Rev. 554 (2015).

201 For a detailed analysis of the origins and usage of the so-called Hippocratic injunction to do harm, see Cedric M. Smith, Origin and Uses of Primum Non Nocere--Above All, Do No Harm! 45 J. Clin. Pharmacology 371 (2005).

202 Peter H. Huang, First Blog Post of the Law School Wellness Project, Stanford Law School Blogs, Aug. 8, 2016, https://law.stanford.edu/2016/08/08/1st-blog-post-of-thelaw-school-wellness-project/.

203 Kathryn M. Stanchi, Who Next the Janitors? A Socio-Feminist Critique of the Status Hierarchy of Law Professors, 73 UMKC L. Rev. 469 (2004). 
The popular notion that law school is an exceptionally stressful experience for many students has been substantiated by longitudinal studies. Indeed, the emotional distress of law students appears to significantly exceed that of medical students and at times to approach that of psychiatric populations. These findings have substantial human and social significance, given that the level of adjustment of graduating law students is likely to carry over into professional practice and may set the stage for the unparalleled frequency of psychological distress and other problems seen broadly among lawyers today. ${ }^{204}$

There have since then been precipitously sharp declines in the demand for legal services ${ }^{205}$ and relatedly, also the demand for professional legal education. ${ }^{206}$ These twin decreases have led to many proposed reforms in the legal profession ${ }^{207}$ and legal education. ${ }^{208} \mathrm{~A}$ commentator observed law schools that are not in the top tier are "hunkering down just long enough until it thins down at the bottom." ${ }^{209}$ Law students who are graduating from the top three law schools, namely Yale, Stanford and Harvard, "will nearly always find security and top-paying work, those attending non-rated or poorly rated schools will struggle as their profession contracts. Even students at moderately rated schools could see their prospects shrink, statistics suggest." 210

James Daily, attorney, Washington law school lecturer, and creator and author of a blog about superheroes, supervillains, and the law, ${ }^{211}$ advocates that "American law schools-at least those associated with universities-should return to offering the LL.B., now as a four-year undergraduate degree, while making the J.D. the research-focused graduate degree it always should have been." ${ }^{212}$ Daily argues that offering the professional law degree to undergraduates, as is the case in most nonU.S. countries has many economic and other benefits coupled with some negligible financial costs to law schools and law students. ${ }^{213}$

The AccessLex Institute, a nonprofit organization "underpinned by nearly 200 American Bar Association-approved nonprofit and state-affiliated law schools," 214 complied a 2017 Legal Education Data Deck, ${ }^{215}$ depicting certain data and trends

204 Kennon M. Sheldon \& Lawrence S. Krieger, Understanding the Negative Effects of Legal Education on Law Students: A Longitudinal Test of Self- Determination Theory, 33 Personality \& Soc. Psychol. Bull. 883, 883 (2007).

205 See, e.g., James E. Daily, Embracing New (and Old) Ideas, 53 Wash. U.J. L. \& PoL'Y 157, 161-63 (2017).

206 Id. at $159-61$.

207 See, e.g., Bruce MacEwen, Growth is Dead: Now What? (2013).

208 See, e.g., Steven J. Harper, The Lawyer Bubble: A Profession in Crisis (2013); Richard SusSkind, TOMORRow's LaWyers: An Introduction to Your Future (2013); Brian Z. Tamanaha, Failing LaW Schools (2012).

209 Greg Toppo, Why You Might Want to Think Twice Before Going to Law School, USA TODAY, June 28, $2017 \mathrm{https} / / / \mathrm{usat} . l \mathrm{ly} / 2 \mathrm{tnE} 3 \mathrm{Ch}$.

210 Id.

211 Law and the Multiverse, http://lawandthemultiverse.com/.

212 Daily, supra note 205, at 166.

213 Id. at $166-68$.

214 About AccessLex Institute, https://www.accesslex.org/about-us.

215 Legal Education Data Deck, https://www.accesslex.org/legal-education-data-deck. 
about access, affordability, and the value of U.S. legal education. This is a living document in the sense that it will be periodically updated. Based on publicly available data, "J.D. degrees awarded per year increased overall between 2003 and 2013, then began to decline in 2014. In 2016, about 37,000 J.D. degrees were awarded." 216 Additionally, "the median salary of recent J.D. graduates is less in 2015 than it was in 2007." "217 Among 1992-1993 bachelor's degree recipients, more than "80 percent of law-related degree recipients felt their education was worth the money." 218 In comparison, only "52 percent of 2007-2008 bachelor's degree recipients who had since earned a graduate degree in legal professions and studies felt their education was worth the cost." 219

\section{B. What Motivates LaW SCHOol Applicants, StUdents, and ALUMNI?}

People apply to and attend law school for many reasons. Because law school is a graduate professional school, most college graduates who apply to law school want to practice law, at least for a while. While there are many things that a person can do as a law school alum, most become lawyers. People desire to become attorneys for many personal and professional reasons, including doing good, fighting for justice, getting rich, having social status, helping people, and making a difference. The rest of this section considers motivations people have in attending law schools.

It has become commonplace to say that students are consumers who buy the commodity of education. A problem with this metaphor is that students are by definition less than fully informed consumers about what it is they are consuming. If they were fully informed, they already would know the information they seek through education. Education is more than information transmission, which takes attention, effort and time, by students and teachers alike. Education entails a set of in-class and related out-of-class experiences, which may have positive or negative affect. Such experiences, though ephemeral, can have lasting impacts in terms of biological consequences and memories. Whether people and society should care more about people's experiences or their memories are intriguing questions. ${ }^{220} \mathrm{Law}$ school can produce memories, possibly fond, of times, possibly good. Law school can also produce memories, possibly unpleasant, of times, possibly stressful.

It has also become commonplace to say that law students are investors in human capital by acquiring the skills of legal analysis. More generally, pursuing any professional degree is a form of investment under uncertainty. Many variables are unknown and likely unknowable, such as future market returns of a professional degree. The past is never a guarantee of the future. The market for attorney services is under intense flux and pressure due to increasing automation, domestic and foreign competition from nonlawyers, and technological changes in the delivery of legal services. ${ }^{221}$

$216 \quad I d$. at 14.

217 Id. at 30 .

$218 \quad I d$. at 31.

219 Id. at 32.

220 Peter H. Huang, Torn Between Two Selves: Should Law Care More About Experiencing Selves or Remembering Selves? 17 S.M.U. Sci. \& Tech. L. Rev. 263 (2014).

221 See, e.g., Benjamin H. Barton \& Stephanos Bibas, Rebooting Justice: More Technology, Fewer LaWyers, and the Future of Law (2017); Mark A. Cohen, When 
For example, Do Not Pay is a completely free lawyer chatbot that democratizes legal assistance, including disputing parking tickets, assisting with landlord disputes, getting compensation from airlines for losing luggage or cancelling flights, disputing credit card charges, disputing credit report items, filing and disputing insurance claims, filing for or extending maternity and paternity leaves, filing complaints with the United States EEOC (Equal Employment Opportunity Commission), and getting consumer product refunds or replacements. ${ }^{222}$ JustFix. nyc is an AI-enhanced website that offers the free service of helping New York City tenants fill out forms to get Housing Court assistance. ${ }^{223}$

The financial costs of attending law school include tuition, living expenses, and opportunity costs. There are also likely emotional costs, such as chronic stress, feeling overwhelmed, and negative impacts on personal relationships. There are even possible mental, physical, and psychological health costs, such as being constantly tired, insomnia, lack of physical exercise, loss of autonomy, substance abuse, and unhealthy eating habits. The benefits of investing in a law school education include financial opportunities that come from being able to practice law, psychological advantages of higher self-esteem and improved social status, and cognitive value of having been exposed to legal analysis. Just what legal analysis is or includes is up to debate. Many law students would say that legal analysis entails analogical reasoning, statutory interpretation, and persuasive legal writing.

Recently, there have been interesting analyses of the value of a J.D. in relation to law student debt and over the course of the business cycle. Law professor and former University of Louisville law school dean Jim Chen utilized mortgage lending guidelines that the Federal Home Administration and private lenders developed to calculate how much of an annual salary a law school graduate has to earn in relation to annual law school tuition to achieve marginal, adequate, and good ratios of income to debt. ${ }^{224}$ Economics professor Frank McIntyre and law professor Michael Simkovic analyze the size and predictability of cohort effects in the premium in earnings from earning a law degree. ${ }^{225}$

Good is Good Enough: Finding The Appropriate Legal Delivery Resources, Forbes, Aug. 3, 2017, 5:54 a.m., https:/www.forbes.com/sites/markcohen1/2017/08/03/whengood-is-good-enough-finding-the-appropriate-legal-delivery-resources/2/\#160f26f96827; Glenn Harlan Reynolds, Legal Automation Spells Relief for Lower-income Americans, Hard Times for Lawyers, USA TODAY, updated 3:55 p.m. ET, Aug. 7, 2017, https://www. usatoday.com/story/opinion/2017/08/07/legal-automation-spells-relief-lower-incomeamericans-hard-times-lawyers/543542001/.

222 Joshua Browder, The World's First Robot Lawyer - Now in 1,000 Legal Areas, You Tube, July 10, 2017, https:/www.youtube.com/watch?v=-rabJDCBUbY; John Mannes, DoNotPay Launches 1,000 New Bots to Help You with Your Legal Problems, TechCrunch, July 12, 2017, https://techcrunch.com/2017/07/12/donotpay-launches-1000-new-botsto-help-you-with-your-legal-problems/.

223 Technology for Housing Justice, JustFix.nyc, https://www.justfix.nyc/our-mission.

224 Jim Chen, A Degree of Practical Wisdom: The Ratio of Educational Debt to Income as a Basic Measurement of Law School Graduates'Economic Viability, 38 WM. MitcheLL L. REv. 1185 (2012). See also Jim Chen, ARM-Twisting “A Degree of Practical Wisdom”: A One-Year Readjustment of Legal Education's Debt-Based Stress Test, MoneyLaw Blog, Oct. 20, 2102, http://money-law.blogspot.com/2012/10/arm-twisting-degree-ofpractical-wisdom.html (revising his analysis).

225 Frank McIntyre \& Michael Simkovic, Timing Law School, 14 J. EmPIRICAL Legal Stud. 258 (2017). 
The market for legal services, like most job markets, involves asymmetric or private information in the sense that people know more about themselves than do potential employers. This informational gap is ameliorated somewhat by employers screening potential employees using such market signals as the U.S. News \& World Report ranking of the law school attended, class ranking, law school G.P.A., and law review membership. So-called white shoe law firms are still hiring and offering high salaries to graduates of top law schools. Students used to joke at SLS that the hardest part about SLS was getting admitted to SLS. Some SLS students did not attend classes, preferring to use commercial study aids and classmates' notes to prepare for their finals.

Although market signals are imperfect proxies for some of the unobservable variables that legal employers care about, they are somewhat informative and free to potential employers. At Yale law school (YLS), where there are only two possible course grades: honors and high honors, some law students work very hard to differentiate themselves from their accomplished colleagues. Because the grades at YLS are noisy and uninformative signals, the many students planning to eventually go into legal academia or seek those prestigious federal judicial clerkships that are known as feeder clerkships for Supreme Court clerkships look for other ways to signal their legal ability, discipline, or work ethic, such as authoring a student note or being a faculty research assistant.

Law school certainly transmits legal information in the form of so-called "black letter" law to law students. More generally and importantly, law schools also transmit what is often called "thinking like a lawyer" or so-called critical thinking skills. ${ }^{226}$ The phrase critical thinking means different things to different people. Many law students would likely say that critical thinking entails a form of learned pessimism, in terms of always thinking about what could possibly go wrong, and being able to criticize arguments by others and oneself, looking for logical fallacies, sloppy reasoning, and unfounded conclusions. People in other parts of a university would include as part of critical thinking quantitative reasoning skills, such as drawing and reading graphs, elementary probabilistic reasoning, and statistical literacy. Very few law students or even law professors would include any quantitative reasoning skills as part of critical thinking because of legal innumeracy. ${ }^{227}$ Former First Lady Michelle Obama, while speaking at the National Science Foundation, described why she chose law to be her career by saying: "I know for me, I'm a lawyer because I was bad at [science and math]. All lawyers in the room, you know it's true. We can't add and subtract, so we argue." ${ }^{228}$ Lack of risk literacy is a serious problem for some law students because the legal profession is becoming more quantitative, technical, and technological.

226 See, e.g., Thomas D. Morgan, The Vanishing American LaWyer 179-81 (2010).

227 James Ming Chen, Legal Quanta: A Mathematical Romance of Many Dimensions, 2016 Мich. Sт. L.J. 313 (2016); Edward K. Cheng, Fighting Legal Innumeracy, 17 GreEN BAG 2D 271 (2014): Lisa Milot, Illuminating Innumeracy, 63 CASE Western L. Rev. 769 (2013); Arden Rowell \& Jessica Bregant, Numeracy and Legal Decision Making, 46 ARIz. ST. L.J. 191 (2014).

228 Michelle Obama, Remarks by the First Lady at the National Science Foundation FamilyFriendly Policy Rollout (Sept. 26, 2011). 
Law students undergo a transformation during law school, in many ways for which students are not always prepared. ${ }^{229}$ This transformative process is an important part of most law students' development of a professional identity. This transformation starts early in law school and can also be uncomfortable, unexpected, and unsettling for some. Law school is not just about information transfer. Law school also is about becoming socialized to the dominant cultures, norms, and mindsets of the legal profession. Such socialization can be more or less foreign. Changes in law students' emotional, mental, and psychological attitudes can be large and painful or small and comforting. At its best, law school benignly transforms law students into lawyers. As the well-known fictional character from the movie Paper Chase, Harvard law school contracts law professor Charles W. Kingsfield Jr. famously said: "You teach yourselves the law, but I train your minds. You come in here with a skull full of mush; you leave thinking like a lawyer."230 Some cynics might joke there is no difference between thinking like a lawyer and having mush in your skull because most lawyers lack quantitative analytical skills. ${ }^{231}$

Law schools teach law students to think like a lawyer, whatever that means exactly. It is helpful to students for professors to be transparent and explicitly state that law school teaches a certain style or way of thinking. ${ }^{232}$ Different law professors usually mean (sometimes very) different sets of things by the phrase, thinking like a lawyer. What it means to think like a lawyer may differ across cultures, ethnicity, gender, generations, law school, practice areas, and regions. Economist Miles Kimball writes about cognitive economics, which he defines as the economics of what is inside people's minds. ${ }^{233}$ Kimball explains that people hire and pay lawyers due to the finiteness of human cognition:

As for lawyers, even if one considers talking in a courtroom a special skill that is not just a matter of intelligence, people pay a lot of money to lawyers who merely read law books and extract the relevant information. If everyone had infinite intelligence, it would be easy to understand the law books on one's own, and paying someone else to do it would only make sense if one's wage rate was higher than the lawyer's wage rate, or if one was a slow reader for physiological reasons. If everyone had infinite intelligence, even finite reading speeds would not give trained lawyers enough of an edge for them to charge the fees they do. ${ }^{234}$

Naturally, law schools teach law students how to read and extract legally relevant information from judicial opinions, regulations, and statutes. Law schools do more than

229 Nelson P. Miller, Going to LaW School: Preparing for a Transformative EXPERIENCE (2016).

230 The Paper Chase (Twentieth Century Fox Film Corp. 1973).

231 But see Howell E. Jackson, Louis Kaplow, Steven Shavell, W. Kip Viscusi, \& David COPE, ANalytical Methods For LaWyers (3rd ed. 2017).

232 Ron Ritchhart, Mark Church, \& Karin Morrison, Making Thinking Visible: How to Promote Engagement, Understanding, and IndePendence for All Learners (2011).

233 Miles Kimball, Cognitive Economics, 66 JAPANESE ECON. Rev. 167, 167 (2015).

234 Id. at 173. 
just merely transmit information though. Law schools also teach law students "how to think like lawyers," a cognitive set of skills that include specific habits of thought. Those habits of thought that may be helpful professionally may not be helpful personally. Cross-examining significant others or one's children is likely to be a bad idea.

Law school alumni vary greatly in their engagement and involvement with their law school. Law school alumni can feel adoration, apathy, connection, contempt, hatred, and indifference towards their law school. Some law school alumni derive a positive sense of identity from being a graduate of their law school. Most people have fond memories of their college days when they became adults. Many people made life-long friends in college. Some people met their spouse or significant other in college. It was and still is commonplace for many students to go to law school directly after graduating from college. Thus, there are law school alumni who also have fond memories of their law school days, made life-long friends in law school, and met their spouse or significant other in law school.

The anxiety, chronic stress depression, and overall unhappiness that many law students have self-reported also means that many law school alumni have quite negative affective memories of their law school days. It also means that some law school alumni want no reminders of their law school days. Traditional five-year reunions offer alumni opportunities to reconnect with their friends (and possibly faculty), reminisce on their law school days, and revisit anew their law school. Those who attend their law school reunions form a proper, self-selected, and possibly unrepresentative subset of their law school alumni.

Overall, law school alumni are motivated to feel good about being a graduate of their law school. This motivation explains why many law school alumni are happy when the ranking of their law school alma matter goes up in the annual U.S. News $\&$ World Report ranking and are unhappy if not upset when the ranking of their law school alma matter falls in the annual U.S. News \& World Report ranking. Happy law school alumni are likely to make supporting their law school alma mater a philanthropic priority, while unhappy law school alumni are not. Fundraising entails building connections and sustaining relationships with potential donors. Potential alumni donors differ in their motives, needs, and expectations. There are seven types of major donors, namely altruist, communitarian, devout, dynast, investor, repayer, and socialite. ${ }^{235}$ Law schools that are successful in fund-raising develop and sustain a positive law school culture among students, alumni, staff, the greater community, and faculty. It is important for a law school's dean to collaboratively craft and successfully communicate to that law school's stakeholders a clear and compelling vision of that law school's core mission(s). The leadership of a successful law school is able to translate that vision into the languages of a law school's diverse constituents in such a way that students, alumni, staff, the greater community, and faculty all feel engaged and part of a positive, organizational culture that helps them flourish and thrive.

235 Russ Alan Prince \& Karen Maru File, The Seven Faces of Philanthropy: A New Approach to Cultivating Major Donors (2001). 


\section{What Motivates Clients of LaW SCHOol GRaduates?}

Clients hire lawyers to help solve legal problems. In litigation, clients hire lawyers to initiate or defend lawsuits. Clients hire lawyers for their legal expertise, practice experience, and problem-solving skills. Litigators also negotiate settlements of lawsuits. In transactional practice, clients hire lawyers to take companies public, defend against hostile takeovers, defend against Department of Justice prosecutions or Securities Exchange Commission (S.E.C.) enforcement actions, perform S.E.C. compliance, draft agreements for corporations, limited liability companies, or limited partnerships, make tender offers, or negotiate mergers or acquisitions. In alternative dispute resolution and mediation, clients hire lawyers to be advocates or neutrals.

Clients often hire lawyers at very emotional and stressful times for the clients. Most clients are not familiar with legalese, legal procedure, and the legal system. Human, as opposed to organizational, clients often despise and fear lawyers, including their own. The American legal system is not user-friendly, except for the knowledgeable and rich. As past Harvard University President and former Harvard law school dean Derek Bok wrote: "There is far too much law for those who can afford it and far too little for those who cannot." ${ }^{236}$ Wealthy individuals and corporations have the financial resources to hire "dream" teams of the best lawyers that money can buy. Poor and even middle-class people often cannot afford to vindicate their most basic human rights and legal rights. There is no shortage of lawyers for corporate America or high net worth individuals. There is vast excess demand for lawyers to represent many even middle-income, let alone low-income, people.

Many lawyers' clients and law firms view lawyers today more as fungible commodities than people. Law once was a noble profession. Law now is a highly competitive business. Medicine and higher education also were once noble professions and now highly competitive businesses. Commodification of law, medicine, and higher education means that employers and customers in law, medicine, and higher education view lawyers, physicians, and professors as being highly interchangeable and replaceable. Such commodification is the result of such inexorable forces as automation, technological progress, and online competition. This commodification is related to a business, economic, and financial perspective to social transactions and market interactions. Conversations about law, medicine, and higher education now routinely utilize the language of benefits, competition, costs, efficiencies, externalities, markets, and tradeoffs. It is contested how individually and socially harmful are economics rhetoric, commodification discourse, and market metaphors. ${ }^{237}$

236 Derek Bok, A Flawed System, Harvard Magazine, May-June 1983, at 38.

237 Margaret J. Radin, Contested Commodities (2001); Kenneth J. Arrow, Invaluable Goods 35 Am. Econ. Rev. 757 (1997) (reviewing Radin's book); Peter H. Huang, Dangers of Monetary Commensurability: A Psychological Game Model of Contagion, 146 U. PA. L. Rev. 1701 (1998); Peter H. Huang, Emotional Reactions to Law and Economics, Market Metaphors, and Rationality Rhetoric, in THEORETICAL Foundations OF LAW AND ECONOMICS 163 (Mark D. White ed., 2009). 
In the last thirty-five years, approximately thirty client-based and attorney-based empirical studies ${ }^{238}$ about lawyering skills establish that so-called soft skills, ${ }^{239}$ such as communication, problem-solving, and resilience determine attorney professional achievement more than legal area expertise. ${ }^{240} \mathrm{~A}$ meta-synthesis of these surveys found eight of the ten most important skills, as ranked by attorneys, are soft skills, namely, ability to assess deals and proposed solutions; ability to assess and mitigate risk; honoring commitments; delegation to and management of support staff; integrity and trustworthiness; keeping information confidential; punctuality; and treating others with courtesy and respect. ${ }^{241}$ That meta-synthesis also revealed nine of the ten most important lawyering skills, as ranked by clients, are soft skills, namely, accurately estimating and clearly explaining attorney fees; communicating with clients; empathy; listening skills, responsiveness to clients; respectfulness; strategic problem solving; trust; and understanding of client needs. ${ }^{242}$

\section{UNHAPPY LAW STUDENTS BECOME UNHAPPY LAWYERS}

An open empirical question is whether legal education must have deleterious effects on law student happiness and well-being. What is empirically resolved is that current legal education does have deleterious effects on the self-reported happiness and subjective well-being of many law students. ${ }^{243}$ It is also even at least partially clear exactly how and why this happens. ${ }^{244}$ This section analyzes what happens when unhappy law students become unhappy lawyers. Unhappy law students become used to being unhappy and/or learn to develop bad habits and coping strategies to deal with their unhappiness, such as self-medication through substance abuse. The substances abused include alcohol, drugs, and unhealthy food.

Alcohol (over)consumption is accepted in the student culture of many law schools. Many law school events and functions routinely serve alcohol. Many law students get together to drink alcohol during a weekly informal "bar review" night, often Thursday before additional drinking at weekends parties and/or tailgating before football games. The lawyer well-being report issued recently by the National Task Force on Lawyer Well-Being explicitly and expressly recommends that law schools deemphasize alcohol at social events and discourage alcohol-centered social events. ${ }^{245}$

The danger of drug abuse is vividly illustrated by the story of Peter, who was a chemist before becoming a high-powered, successful patent lawyer. ${ }^{246}$ Peter had made partner in the IP practice of Wilson Sonsini Goodrich \& Rosati, a Silicon

238 Randal Kiser, Soft Skills for the Effective LaWyer 25-26, n.5, 26-33, 292-302 (2017).

239 Id. at 4,6 , tbl. 1.1 .

240 Id. at 32-33.

241 Id. at 34-35, tbl. 2.1.

242 Id. at 34-35, tbl. 2.1.

243 Krieger \& Sheldon, supra note 193.

244 Krieger, supra note 194; Sheldon \& Krieger, supra note 204.

245 National Task Force on Lawyer Well-Being, supra note 19, at 4, 5, 11, 19, 33, 40, n. 159 .

246 Eilene Zimmernan, The Lawyer, the Addict, N.Y. Times, July 16, 2017, at BU1. 
Valley law firm that describes itself on its company website as "the premier legal advisor to technology, life sciences, and other growth enterprises worldwide." 247 Peter died alone a drug addict in his home July 2015 from a systemic bacterial infection due to intravenous drug usage. Eilene, his ex-wife, found in Peter's house a cornucopia of drugs including Adderall, cocaine, crystal meth, Tramadol, and Vicodin. Eilene observed that "drug abuse among America's lawyers is on the rise and deeply hidden." ${ }^{248}$

Eileen told Peter's heart-breaking story, including a sad, haunting fact that the last call Peter made on his cell phone was a conference call into work. ${ }^{249}$ Peter is unfortunately only one of all too many lawyers who deal privately and silently with a highly stressful professional work life and self-medicate through substance abuse. ${ }^{250}$ There are well-known disturbing, sobering, and tragic statistics about the percentage of lawyers suffering from anxiety, depression, and problem drinking, or self-medicating with cocaine, crack, hash, marijuana, opioids, sedatives and stimulants. ${ }^{251}$ Compounding problems of alcohol and prescription drug abuse are some law firm cultures of avoidance and conspiracies of silence that fail to acknowledge that addiction is a disease..$^{252}$

The fictional AMC television series Better Call Saul viscerally showed the possible tragic consequences that can result from lawyers who are suffering chronic stress and mental illness. ${ }^{253}$ In the penultimate episode of the third season of the series, ${ }^{254} \mathrm{Kim}$ Wexler, law partner of the titular character, became fatigued and worn down mentally and physically from overwork and self-induced stress. Kim fell asleep driving, crashed her car into a boulder, and broke her arm. In the next and final episode of the season, ${ }^{255}$ Chuck McGill, brother of the titular character, was forced out of a law firm that bore his name (Hamlin, Hamlin \& McGill) and became obsessed with disabling every electronic device in his home to such an extent that he tore open walls to remove wiring. Chuck finally broke down and knocked over a gas lantern on purpose to set fire to his house, while still inside

247 Wilson Sonsini Goodrich248 \& Rosati Website, About Us, https:/www.wsgr.com/ WSGR/Display.aspx?SectionName=about.

248 Id. See also Eilene Zimmernan, The Lawyer, the Addict, N.Y. Times, Business DaY, July 15, 2017, https://www.nytimes.com/2017/07/15/business/lawyers-addiction-mentalhealth.html (online version).

249 See also Debra Cassens Weiss, BigLaw Partner Managed to Dial in to Work Conference Call Before His Drug-Related Death, A.B.A. J., Work-Life Balance, July 19, 2017, 7:00 a.m. C.D.T., http://www.abajournal.com/news/article/drug_addicted_biglaw_partner_ managed_to_dial_in_to_work_conference_call_bef/?utm_source $=$ maestro\&utm medium=email\&utm_campaign=weekly_email.

250 See, e.g., Debra S. Austin, Drink Like a Lawyer: The Neuroscience of Substance Use and Its Impact on Cognitive Wellness, 15 Nev. L.J. 826 (2015). See also Brian Cuban, Staying 'Well' in Law School, Aвоve the Law, Aug. 9, 2017, 2:47 pm, http://abovethelaw. com/2017/08/staying-well-in-law-school/?rf=1; CuBAN, supra note 28.

251 See, e.g., Krill, Johnson, \& Albert, supra note 27; Dave Nee Foundation, Lawyers \& Depression, http://www.daveneefoundation.org/scholarship/lawyers-and-depression/.

252 Zimmerman, supra note 246.

253 Adam Banner, 'Better Call Saul' Highlights Stress and Mental Illness in the Legal Profession, ABA J., July 31, 2017, 8:30 am CDT, http://www.abajournal.com/news/ article/better_call_saul_highlights_stress_and_mental_illness_in_the_legal_professi.

254 Better Call Saul: Fall (AMC television broadcast June 12, 2017).

255 Better Call Saul: Lantern (AMC television broadcast June 19, 2017). 
the house. The Centers for Disease Control and Prevention reported in 2014 that lawyers ranked fourth in the proportion of suicides in the profession, behind only dentists, pharmacists and physicians. ${ }^{256}$

Eilene remembers Peter working over sixty hours every week for twenty years ever since he started law school. Peter was a law review editor who graduated number one is his law school class and spoke at his commencement. ${ }^{257}$ Law school can often be boring, exhausting, painful, stressful, and tedious. Some law students develop bad habits in law school about how to manage their stress. Many law students suffer from anxiety, depression, despair, hostility, learned pessimism, and unhappiness. ${ }^{258}$ Lawyers often learn in law school to become highly, perhaps overly critical, detailed, and focused thinkers who approach legal problems in exclusively analytical, deliberative, and logical terms, eschewing all emotions. ${ }^{259}$

\section{E. What Motivates LaW PRofessors?}

Law professors engage in teaching, scholarship, and service. Motivations of law professors for teaching, scholarship, and service are as varied as law professors. Some law professors only enjoy and/or are capable of doing well one of teaching, scholarship, and service. Other law professors enjoy and/or are capable of doing well all three of teaching, scholarship, and service.

In introductory economics courses, students learn the principle of comparative advantage in discussing the gains from international trade. British economist David Ricardo published in chapter seven of his political economy treatise, ${ }^{260}$ his classical theory of comparative advantage to explain why trade among two or more countries can be mutually beneficial, even if one country's labor force is more efficient at producing every single commodity than laborers in other countries. Applying the concept of comparative advantage to people and tasks implies that it would be most economically efficient for people to specialize in doing tasks in which they have a comparative advantage.

Considerations of equity, fairness, or tradition prevent having professors specializing in only doing one of teaching, scholarship, and service. There are de facto exceptions in the form of reduced teaching loads for professors who excel at research or service. In the natural and social sciences, it is common for professors to apply for and be granted external research funds that explicitly include buying time off from some or all of a professor's teaching to do research. Some professors are able to effectively teach little if at all as long as they are able to secure highly competitive research grants and their renewals. This is especially true at higherranked research universities. There are no Nobel laureates in teaching excellence. In medical schools, professors often pay for laboratory space and part of their

256 Flores \& Arce, supra note 190.

257 Zimmernan, supra note 248.

258 Todd Peterson \& Elizabeth Waters Peterson, Stemming the Tide of Law Student Depression: What Law Schools Need to Learn from the Science of Positive Psychology, 9 Yale J. Health Pol'y, L., \& Ethics 357 (2009).

259 Elizabeth Mertz, The Language of Law School: Learning to "Think Like a LAWYER" (2007).

260 David Ricardo, On the Principles of Political Economy and Taxation 77-93 (1817, 2004 ed.). 
salaries from external research funding sources. Most grants also pay for overhead and often summer salaries. In law schools, professors do not have a tradition of having to apply for and secure external research funds.

Teaching and service can be fulfilling, though often labor-intensive and time-consuming. Both teaching and service also usually entail developing what economists would call firm-specific human capital. In other words, teaching and service are less observable and transferable than research. Publications are public information and proof of the ability to do research. Most professors have a research agenda or plan in the sense of multiple publications. Some professors believe in the concept of publishing only the least publishable unit of work product. Other professors publish the same idea multiple times in slightly different publications. Law reviews exacerbate these problems because law reviews are not peer-refereed, permit multiple, simultaneous submissions, and expedite manuscript reviews based on the signal of acceptance by lower-ranked law reviews. A recent law review article cleverly parodies and satirizes law review articles in general. ${ }^{261}$

My law school's current dean presented this top five list of reasons that law professors do research and write articles. ${ }^{262}$ The number five reason that law professors write articles is for their family and themselves to be proud of what they do. The number four reason that law professors write articles is for promotion, tenure, and post-tenure review. The number three reason that law professors write articles is to experience the collegiality and camaraderie when making presentations at colloquia, conferences, meetings, seminars, and workshops. The number two reason that law professors write articles is to have or make an impact, be that among law professors, law and public policy makers, judges, the public, or society-atlarge. The number one reason that law professors write articles is to achieve or sustain happiness or joy in terms of finding and having meaning and purpose.

Law professors can and should teach law students to become life-long learners who embrace curiosity, ${ }^{263}$ asking their own questions, ${ }^{264}$ and exceling at deep inquiry and imaginative questioning. ${ }^{265}$ Law professors can and should create a culture of thinking in law school classrooms by utilizing these eight cultural forces: expectations, language, time, modeling, opportunities, routines, interactions, and environment. ${ }^{266} \mathrm{~A}$ thinking culture

is not about just adhering to a particular set of practices or a general expectation that people should be involved in thinking. A culture of thinking produces the feelings, energy, and even joy that can propel

261 Pierre Schlag, The Law Review Article, 88 U. Colo. L. Rev. 1043 (2017).

262 S. James Anaya, Presentation at the University of Colorado Law School faculty scholarship retreat, Making a Difference: Impactful Legal Scholarship, May 20, 2017, Stanley Hotel, Estes Park, CO.

263 Brian Grazer, A Curious Mind: The Secret to a Bigger Life (2015).

264 Dan Rothstein \& Luz Santana, Make Just One Change: Teach Students to Ask THEIR OWN Questions (2011).

265 Warren Berger, A More Beautiful Question: The Power of Inquiry to Spark BREAKTHROUGH IDEAS (2016).

266 Ron Ritchhart, Creating Cultures of Thinking: The 8 Forces We Must Master to Truly Transform Our Schools (2015). 
learning forward and motivate us to do what at times can be hard and challenging mental work. ${ }^{267}$

\section{Ways to Teach LaW Students About HappinesS AND MINDFULNESS}

Law professors can and should teach law students about empirically validated well-being mindsets, skills, strategies, techniques, and tools proven to mitigate the likelihood, duration, and severity of anxiety, depression, and chronic stress. Part III of the Article offers many possible resources to help law professors do this. First, this part of the Article discusses approaches that law professors, lawyers, and others have developed or suggested to teach law students about happiness and mindfulness. Second, this part of the Article discusses my experiences teaching law students about happiness and mindfulness. This discussion will be brief because I have already written elsewhere extensively about my experiences teaching about happiness and mindfulness to law students in torts, legal ethics and professionalism, economic analysis of law, neuroscience and law, media, law, and popular culture. ${ }^{268}$

\section{A. Resources to TeaCh LaW Students About HappinesS and MindFulNESS}

Law professors Nancy Levit and Douglas Linder co-authored a wonderful book about happiness for law students and lawyers, ${ }^{269}$ for which they also created a webpage of resource materials. ${ }^{270}$ They also wrote another terrific book about how to be a better and more fulfilled lawyer, ${ }^{271}$ accompanied by another webpage of resource materials. ${ }^{272}$ Two law professors recently wrote books about the business of being a lawyer that contain sections about well-being. ${ }^{273} \mathrm{~A}$ chapter in a handbook about well-being surveys applications to law, including legal education and the practice of law. ${ }^{274}$

A recent meta-analysis of twenty-nine studies, involving a total of 3319 participants, found training interventions can increase optimism and various factors increasing significantly effect size, such as utilizing a visualizing the best possible

267 Id. at 5.

268 Huang, supra note 1; Huang, supra note 2.

269 Nancy Levit \& Douglas O. Linder, The Happy Lawyer: Making a Good Life in the LAW (2010).

270 The Happy Lawyer: Making a Good Life IN THE LAw, http://law2.umkc.edu/faculty/ projects/ftrials/happylawyers/thehappylawyer.html.

271 Douglas O. Linder \& Nancy Levit, The Good Lawyer: Seeking Quality in the Practice OF LAW (2014).

272 The Good Lawyer: Seeking Quality in the Practice of Law, http://law2.umkc.edu/ faculty/projects/ftrials/GoodLawyer/aboutgoodlawyer.html.

273 Katrina Lee, The Legal Career: Knowing the Business, Thriving in Practice 23154 (2017); Pamela Bucy Pierson, The Business of Being a Lawyer (2014).

274 Peter H. Huang, Subjective Well-Being and the Law, in HandBooK ON Well-BeInG (Ed Diener, Shige Oishi, \& Louis Tay eds., 2018), https://www.nobascholar.com/chapters/56. 
self exercise and providing the intervention in-person. ${ }^{275}$ Law professors can and should create optimistic classrooms. ${ }^{276}$ The Association of American Law Schools Section on Balance in Legal Education, ${ }^{277}$ which "seeks to investigate, discover, and inspire those practices that support the well-being of law students, lawyers, and judges," 278 maintains a bibliography of scholarship "related to Humanizing/ Balance in Legal Education" 279 organized by topic.

There are many books about happiness that law professors can learn from and assign (parts of) as required or optional reading to law students, including these: a handbook that is the positive psychology analogue of the current and fifth edition of the Diagnostic and Statistical Manual of Mental Disorders (DSM-V), ${ }^{280}$ a positive psychology handbook, ${ }^{281}$ a trade book providing an easy-to-read interdisciplinary overview and review about happiness by a psychologist, ${ }^{282}$ an undergraduate positive psychology paperback textbook, ${ }^{283}$ a trade book about positive psychology, ${ }^{284}$ a book that won the 2008 professional and scholarly publishing division of the association of American publishers prose award for excellence in psychology by a co-founder of positive psychology, ${ }^{285}$ a trade book by a popular teacher of positive psychology at Harvard, ${ }^{286}$ a book about being in the "zone" by another co-founder of positive psychology, ${ }^{287}$ a user-friendly trade book about positive psychology, ${ }^{288}$ a tour of different philosophies about happiness, ${ }^{289}$ another excellent undergraduate positive psychology paperback textbook, ${ }^{290}$ a trade book about happiness by a psychotherapist, ${ }^{291}$ a trade book about how to achieve and sustain happiness by a

275 John M. Malouff \& Nicola S. Schutte, Can Psychological Interventions Increase Optimism? A Meta-Analysis, 12 J. Positive Psychology 594 (2017).

276 Corie Rosen, Creating the Optimistic Classroom: What Law Schools Can Learn from Attribution Style Effects, 42 McGeorge L. Rev. 319 (2011).

277 AALS Section on Balance in Legal Education, http://www.balanceinlegaleducation. org/.

$278 \mathrm{http}: / / w w w . l a w . d u . e d u / i n d e x . p h p / a a l s-b a l a n c e-i n-l e g a l-e d u c a t i o n-b i b$.

$279 \mathrm{http} / / / w w w . b a l a n c e i n l e g a l e d u c a t i o n . o r g /$ resources/resources/bibliography.html.

280 Character Strengths and Virtues: A Handbook and Classification (Christopher Peterson \& Martin E.P. Seligman eds., 2012).

281 Shane J. Lopez, Jennifer Teramoto Pedrotti, \& Charles Richard Synder, Positive Psychology: The Scientific and Practical Exploration of Human Strengths (3d ed., 2014).

282 Daniel Nettle, Happiness: The Science behind Your Smile (2006).

283 Martin Bolt \& Dana S. Dunn, Pursuing Human Strengths: A Positive Psychology GUIDE (2d ed., 2015).

284 Jonathan Haidt, The Happiness Hypothesis: Finding Modern Truth in Ancient WisDOM (2006).

285 Ed Diener \& Robert Biswas-Diener, Happiness: Unlocking the Mysteries of Psychological Wealth (2008).

286 Tal Ben-Shahar, Happier: Learn the Secrets to Daily Joy and Lasting FULFILLMENT (2007).

287 Mihaly Csikszentminalyi, Flow: The Psychology of Optimal Experience (2008).

288 Bridget Grenville-Cleave, Positive Psychology: A Practical Guide (2012).

289 Will Buckingham, Happiness: A Practical Guide (2012).

290 William C. Compton, Positive Psychology: The Science of Happiness and Flourishing (2d ed., 2012).

291 Richard Carlson, You Can Be Happy No Matter What (15th anniversary ed. 2006). 
positive psychologist, ${ }^{292}$ that is based partly on a related research article, ${ }^{293}$ and a trade book by an authority on positive psychology about strategies for leading a less stressful and more joyful, meaningful, and mindful life. ${ }^{294}$

An entertaining video introduction to research about happiness and positive psychology is a documentary Happy, ${ }^{295}$ which features visually compelling vignettes interviewing happy and unhappy people in different countries interspersed with brief segments that showcase various leading positive psychologists and neuroscientists who study happiness. ${ }^{296}$ A recent special issue of Time magazine includes sixteen general interest articles discussing the practical implications of recent scientific research about happiness. ${ }^{297}$ An excellent master's in applied positive psychology capstone project by attorney Anne Brafford, Building the Positive Law Firm: The Legal Profession at Its Best ${ }^{298}$ develops a blueprint for how to utilize insights from positive psychology and positive organizational scholarship to design a law firm in which attorneys, clients, and communities thrive. Another excellent master's in applied positive psychology capstone project by attorney Martha Knudson, Building Attorney Resources: Helping New Lawyers Succeed Through Psychological Capital details how psychological capital ${ }^{299}$ in the form of confidence, hope, optimism, and resilience helps lawyers and law students develop a competitive edge. ${ }^{300}$ A chapter in a handbook about positive psychology discusses how to create positive law schools and positive law firms. ${ }^{301}$ Appendix $\mathrm{E}$ of the

292 Sonja Lyubomirsky, The How of Happiness: A New Approach to Getting the Life You Want (2008).

293 Sonja Lyubomirsky, Kennon M. Sheldon, \& David Schkade, Pursuing Happiness: The Architecture of Sustainable Change, 9 Rev. Gen. Psychol. 111 (2005).

294 Beth Cabrera, Beyond Happy: Women, Work, and Well-Being (2015).

295 HAPPY (Wadi Rum Productions 2011).

296 There are appearances by Greg Berns, Mihaly Csikszentmihalyi, Richard Davidson, Ed Diener, Daniel Gilbert, Sonja Lyubomirsky, Tim Kasser, Nic Marks and Read Montague.

297 The Science of Happiness: New Discoveries for A More Joyful Life, Time, (Siobhan O'Connor ed., updated reissue of special ed. 2016, 2017).

298 Anne M. Brafford, Building the Positive Law Firm: The Legal Profession at Its Best, Master of Applied Positive Psychology Capstone Projects 62, University of Pennsylvania Scholarly Commons, Aug. 1, 2014, http://repository.upenn.edu/cgi/viewcontent. cgi?article=1063\&context=mapp_capstone. See also Anne M. BrafFord, Positive Professionals: Creating High-Performing Profitable Firms Through the Science of Engagement (2017); Anne M. Brafford, Transform Lawyer Well-Being into a Team Sport, in The Best Lawyer You Can Be: A Guide to Physical, Mental, Emotional, and Spiritual Wellness 41 (Stewart Levine ed., 2018)

299 Fred luthans, Carolyn M. Youssef, \& Bruce J. Avolio, Psychological Capital: Developing the Human Competitive Edge (2007).

300 Martha Knudson, Building Attorney Resources: Helping New Lawyers Succeed Through Psychological Capital, Master of Applied Positive Psychology Capstone Projects 83, University of Pennsylvania Scholarly Commons, Aug. 1, 2015, http://repository.upenn. edu/cgi/viewcontent.cgi?article $=1084 \&$ context $=$ mapp_capstone. See also Martha Knudson, Psychological Capital and Lawyer Success, in The Best Lawyer You Can Be: A Guide to Physical, Mental, Emotional, and Spiritual Wellness 151 (Stewart Levine ed., 2018).

301 Peter H. Huang, Anne M. Brafford, Debra S. Austin, \& Martha Knudson, Positive Institutions: Organizations, Laws, and Policies, in The Oxford Handbook of Positive Psychology (C.R. Snyder, Shane J. Lopez, Lisa M. Edwards, \& Susana C. Marques eds., 2018). See also Peter H. Huang, Happiness 101 for Legal Scholars: Applying Happiness 
National Task Force on Lawyer Well-being report, The Path to Lawyer Well-being: Practical Recommendations for Positive Change, ${ }^{302}$ offers additional readings, resources, and topics for "creating a well-being course and lecture series for law students." ${ }^{303}$ Appendix B of the report provides "Example Educational Topics for Lawyer Well-Being, ${ }^{304}$ including mindfulness meditation. ${ }^{305}$

A straightforward and pragmatic definition of mindfulness is as "the ability to know what's happening in your head at any given moment without getting carried away by it." ${ }^{\prime 306}$ A commercial real estate attorney provides a very brief (one and one-quarter page) pragmatic, terrific introduction to why and how lawyers should practice mindfulness (including two short, simple, sample mini-exercises in practicing mindfulness). ${ }^{307}$ There is a YouTube video of Andy Puddicombe, founder of the meditation app Headspace with approximately eighteen million users, leading a two-minute guided mediation on the Tonight Show Starring Jimmy Fallon. ${ }^{308}$ A podcast of an American Bar Association webinar titled, Mindfulness: A Pathway to Success, Happiness, and Conflict Resolution ${ }^{309}$ includes the slides from a PowerPoint presentation about how mindfulness can benefit law students and lawyers. An introduction to mindfulness designed for law students and young lawyers is an American Bar Association law student division webinar presentation by Cory Muscara, an attorney who also holds a master's degree in applied positive psychology, about how to manage stress and shift from just surviving to flourishing and thriving. ${ }^{310}$

A number of law professors, bar associations, and law schools offer law students courses and programs about mindfulness. Northwestern University law school Harris H. Agnew Visiting Professor of Dispute Resolution Leonard L. Riskin ${ }^{311}$

Research to Legal Policy, Ethics, Mindfulness, Negotiations, Legal Education, and Legal Practice, in Research Handbook on Behavioral Law and Economics 271, 286-88 (Joshua C. Teitelbaum \& Kathryn Zeiler eds., 2018) (providing a primer for law professors about happiness in legal education and legal practice).

302 National Task Force on Lawyer Well-Being, supra note 19, at 61-62.

303 Id. at 61.

304 Id. at 50-57.

305 Id. at 52-53.

306 Happify, Why Mindfulness Is a Superpower: An Animation, Dec. 7, 2015 (available at https://www.youtube.com/watch?v=w6T02g5hnT4).

307 Gisela M. Munoz, Meant to Be, Dade County Bar Ass'n Bull., Mar. 2017, at 4-5.

308 The Tonight Show Starring Jimmy Fallon, Andy Puddicombe Guides Jimmy Through a Two-Minute Headspace Meditation, Aug. 4, 2017, https://www.youtube.com/ watch?v=kP_EY7pdTJY.

309 American Bar Association Section of Science \& Technology Law, Behavioral and Neuroscience Law Committee, and Membership and Diversity Committee, Mindfulness: A Pathway to Success, Happiness, and Conflict Resolution, Mar. 24, 2016, http://www. americanbar.org/content/dam/aba/events/science_technology/2016/2016mindfulness. authcheckdam.pdf.

310 American Bar Association Law Student Division and Young Lawyer Division, Mindfulness Meditation: Managing Stress and Shifting from Surviving to Thriving, Mar. 31, 2016 (available at https://www.youtube.com/watch?v=_so1P482XGc).

311 Leonard L. Riskin, Faculty Page, Northwestern Law School, http://www.law. northwestern.edu/faculty/profiles/LeonardRiskin/. 
pioneered the introduction of mindfulness in law schools, ${ }^{312}$ dispute resolution, ${ }^{313}$ conflict resolution, ${ }^{314}$ and negotiation. ${ }^{315}$ University of Miami law professors Jan Jacobowitz, director of the Professional Responsibility and Ethics Program, ${ }^{316}$ and Scott Rogers, founder and director of the Mindfulness in Law Program, ${ }^{317}$ co-teach an innovative version of the required professional responsibility course that is organized around mindfulness and social media/technology, called Mindful Ethics: Professional Responsibility for Lawyers in the Digital Age. ${ }^{318}$ University of Miami law professor William Blatt ${ }^{319}$ teaches a course titled Emotional Intelligence, ${ }^{320}$ which is related to mindfulness as emotional intelligence is mindfulness about emotions. Principal Analyst at DecisionSet ${ }^{\circledR}$ in Palo Alto, California, Randall Kiser wrote a unique multi-disciplinary, practice-based book that introduces these important soft skills to law students: self-awareness, self-development, social proficiency, wisdom, leadership, and professionalism, ${ }^{321}$ and includes masterful coverage of mindfulness, equanimity, and well-being. ${ }^{322}$

University of New Mexico law professor Nathalie Martin co-authored a book about yoga for lawyers, ${ }^{323}$ advocates that law schools incorporate mindfulness, professional identity, and emotional intelligence into the first year curriculum, ${ }^{324}$ and wrote a wonderful text for law students about how to craft professional

312 Leonard L. Riskin, Awareness and the Legal Profession: An Introduction to the Mindful Lawyer Symposium, 61 J. Legal Educ. 634 (2012); Leonard L. Riskin, The Contemplative Lawyer: On the Potential Contributions of Mindfulness Meditation to Law Students, Lawyers, and their Clients, 7 Harv. Negot. L. Rev. 1 (2002).

313 Leonard L. Riskin, Awareness and Ethics in Dispute Resolution and Law: Why Mindfulness Tends to Foster Ethical Behavior, 50 S. Tex. L. Rev. 493 (2009).

314 Leonard L. Riskin \& Rachel Wohl, Mindfulness in the Heat of Conflict: Taking STOCK, 20 Harv. Negot. L. Rev. 121 (2015); Leonard L. Riskin, Managing Inner and Outer Conflict: Selves, Subpersonalities, and Internal Family Systems, 18 HaRv. NeGOT. L. Rev. 1 (2013).

315 Leonard L. Riskin, Negotiation, Outside-In and Inside-Out: On the Level or Thereabout, 43 Ohio N.U. L. Rev. 399 (2017); Leonard L. Riskin, Beginning with Yes: A Review Essay on Michael Wheeler's the Art of Negotiation: How to Improvise Agreement in a Chaotic World, 16 CARdozo J. Conflict Resol. 605 (2015); Leonard L. Riskin, Annual Saltman Lecture: Further Beyond Reason: Emotions, the Core Concerns, and Mindfulness in Negotiation 10 Nev. L.J. 289 (2010).

316 Jan L. Jacobowitz, Faculty Page, University of Miami Law School, http://www.law. miami.edu/faculty/jan-1-jacobowitz.

317 Scott L. Rogers, Faculty Page, University of Miami Law School, http://www.law.miami. edu/faculty/scott-l-rogers.

318 Mindful Ethics: Professional Responsibility for Lawyers in the Digital Age, Course Page, University of Miami Law School, https://lawapps2.law.miami.edu/clink/course. aspx?cof id $=1472$.

319 William Blatt Faculty Page, http://www.law.miami.edu/faculty/william-s-blatt.

320 https://lawapps2.law.miami.edu/clink/course.aspx?cof_id=2479.

321 Kiser, supra note 238.

322 Id. at $129-35$.

323 See e.g., Hallie Neuman Love \& Nathalie Martin, Yoga for Lawyers: Mind-Body Techniques to Feel Better All the Time (2015). See also Nathalie Martin, The Lawyer in the Lotus, in The Best Lawyer You Can Be: A Guide to Physical, Mental, Emotional, and SpiRitual Wellness 69 (Stewart Levine ed., 2018).

324 Nathalie Martin, Think Like a (Mindful) Lawyer: Incorporating Mindfulness, Professional Identity, and Emotional Intelligence into the First Year Law Curriculum, 36 U. Ark. Little Rock L. Rev 413 (2014). 
identity through practicing mindfulness and emotional intelligence. ${ }^{325}$ University of San Francisco law professor Rhonda Magee, ${ }^{326}$ has written about how and why to teach lawyers to meditate, ${ }^{327}$ how mindfulness can help educate lawyers about how to confront racism, ${ }^{328}$ and the role of mindfulness practices in enhancing understanding of race and its pervasive influence in our lives and in the law. ${ }^{329}$ Brooklyn University director of legal writing and law professor Heidi K. Brown has written about mindful legal writing ${ }^{330}$ and the importance of active listening, empathy, contemplative analysis, and impactful writing. ${ }^{331}$ A case study about housing development in west Oakland, California demonstrates how practicing mindfulness can help lawyers best advocate for economic justice on behalf of disenfranchised and subordinated communities. ${ }^{332}$

Southwestern law professor Rebecca Ann Simon, ${ }^{333}$ co-directs an innovative, science-based, and voluntary IL "Peak Performance Program" to help new law students de-stress, focus, and perform well in law school. ${ }^{334}$ Professor Simon also is executive director of the national Mindfulness in Law Society (MILS), a national community of lawyers, law students, faculty, judges, and others in the legal profession who seek to improve and promote the mental health and well-being of law students and those in the legal profession through mindfulness practices. ${ }^{335}$ The MILS website includes a set of mindfulness resources. ${ }^{336}$

325 Nathalie Martin, Lawyering from the Inside Out: Learning Professional DeVelopment through Mindfulness And EMOTIONAL INTELligence (2018).

326 Rhonda Magee Faculty Page, University of San Francisco School of Law, https:/www. usfca.edu/law/faculty/rhonda-magee.

327 Rhonda V. Magee, Educating Lawyers to Meditate? From Exercises to Epistemology to Ethics: The Contemplative Practice and Law Movement as Legal Education Reform, 79 UMKC. L. REv. 535 (2011).

328 Rhonda V. Magee, Reacting to Racism: Mindfulness Has a Role in Educating Lawyers to Address Ongoing Issues., ABA J., Aug. 2016, at 26.

329 Rhonda V. Magee, The Way of ColorInsight: Understanding Race and Law Effectively Through Mindfulness-Based ColorInsight Practices, 8 Geo. J.L. \& CRITICAL RACE PERSP. 251 (2016).

330 Heidi K. Brown, The Mindful Legal Writer: Mastering Predictive And Persuasive Writing (2016); Heidi K. Brown, The Mindful Legal Writer: Mastering Persuasive Writing (2016); Heidi K. Brown, The Mindful Legal Writer: Mastering Predictive Writing (2015).

331 Heidi K. Brown, The Introverted Lawyer: A Seven Step Journey Toward Authentically Empowered Advocacy (2017).

332 Angela Harris, Margaretta Lin \& Jeff Selbin, From the Art of War to Being Peace: Mindfulness and Community Lawyering in a Neoliberal Age, 95 CAL. L. REv. 2073 (2007).

333 Rebecca Ann Simon Faculty Page, Southwestern Law School, http://www.swlaw.edu/ faculty/full-time/rebecca-simon.

334 Southwestern Law School Los Angeles, Mindfulness, Peak Performance, and Wellness Programs, http://www.swlaw.edu/student-life/support-network/mindfulness-peakperformance-and-wellness-programs; Mindfulness, Stress Management, and Peak Performance Program Brochure, http:/www.swlaw.edu/sites/default/files/2017-05/ SLS 7x7booklet_EMAIL.pdf; Peak Performance Program Sessions, http://www.swlaw. edu/sites/default/files/2017-08/Peak\%20Performance\%20Sessions\%202017.pdf.

335 Mindfulness in Law Society Website, http://mindfulnessinlawsociety.com/.

336 Mindfulness in Law Society Resources, http://mindfulnessinlawsociety.com/resources/. 
Law professors can also learn from and assign several brief articles from the Harvard Business Review about mindfulness, including a discussion of business implications of neuroscience research about mindfulness, ${ }^{337}$ an interview with psychologist Ellen Langer discussing her pioneering research about mindfulness, ${ }^{338}$ empirical evidence the benefits of mindfulness require practice, ${ }^{339}$ possible pitfalls from practicing mindfulness, ${ }^{340}$ an explanation of how practicing just ten minutes of mindfulness daily subtly changes reactions to everything and improves decisionmaking, ${ }^{341}$ recommendations for how to successfully design a mindfulness program for corporate leadership, ${ }^{342}$ and research finding that practicing mindfulness improves leadership through improving emotional intelligence competencies. ${ }^{343}$

Law professors can learn from and assign (parts of) as required or optional reading to law students many books about mindfulness, including these: a trade book by an Ohio Congressman about how mindfulness can help reinvigorate the American Dream; $; 44$ any of many trade books by a renowned Vietnamese Zen master, poet, and peace activist, ${ }^{345}$ a trade book by a clinical psychologist, co-founder of the Insight Meditation Society and the Spirit Rock Center, ${ }^{346}$ any of many trade books by, any of many trade books by the founder of Mindfulness-Based Stress Reduction (MBSR), ${ }^{347}$ two trade books by a former software engineer and Google employee

337 Christina Congleton et al., Mindfulness Can Literally Change Your Brain, HaRv. Bus. REV., Jan. 8, 2015, https://hbr.org/2015/01/mindfulness-can-literally-change-your-brain.

338 Ellen Langer \& Allison Beard, Mindfulness in the Age of Complexity, HaRv. Bus. REv., Mar. 2014, at 68, 70-72.

339 Megan Reitz \& Michael Chaskalson, Mindfulness Works but Only If You Work at It, Harv. Bus. Rev., Nov. 4, 2016, https://hbr.org/2016/11/mindfulness-works-but-only-ifyou-work-at-it.

340 David Brendel, There Are Risks to Mindfulness at Work, Harv. Bus. Rev. Feb. 11, 2015, https://hbr.org/2015/02/there-are-risks-to-mindfulness-at-work.

341 Rasmus Hougaard, Jacqueline Carter, \& Gitte Dybkjaer, Spending 10 Minutes a Day on Mindfulness Subtly Changes the Way You React to Everything, Harv. Bus. Rev., Jan. 18, 2017, https://hbr.org/2017/01/spending-10-minutes-a-day-on-mindfulness-subtlychanges-the-way-you-react-to-everything.

342 Megan Reitz \& Michael Chaskalson, How to Bring Mindfulness to Your Company's Leadership, Harv. Bus. Rev., Dec. 1, 2016.

343 Daniel Goleman \& Matthew Lippincott, Without Emotional Intelligence, Mindfulness Doesn't Work, Harv. Bus. Rev., Sept. 8, 2017, https:/hbr.org/2017/09/sgc-what-reallymakes-mindfulness-work.

344 Tim Ryan, A Mindful Nation: How a Simple Practice Can Help Us Reduce Stress, Improve Performance, ANd Recapture the American Spirit (2013).

345 See, e.g., Thich Nhat Hanh, The Art of Living: Peace and Freedom in the Here and Now (2017); How to Relax (2015); Thich Nhat Hanh, You Are Here: Discovering the Magic of the Present Moment (2010); Thich Nhat Hanh, Peace Is Every Step: The Path of Mindfulness in Everyday Life (1992); Thich Nhat Hanh, The Miracle of Mindfulness: An Introduction to the Practice of Meditation (1999).

346 JaCK Kornfield, Meditation for Beginners (2008).

347 See, e.g., John Kabat-Zinn, Mindfulness for Beginners: Reclaiming the Present Moment and Your Life (2016); John Kabat-Zinn, Full Catastrophe Living (Revised Edition): Using the Wisdom of Your Body and Mind to Face Stress, Pain, and Illness (rev'd. updated ed. 2013); John Kabat-Zinn, LetTing Everything Become Your Teacher: 100 Lessons in Mindfulness (2009); John Kabat-Zinn, Arriving at Your Own Door: 108 Lessons in Mindfulness (2007); John Kabat-Zinn, Coming to Our Senses: Healing Ourselves and the World Through Mindfulness (2006); 
number 107 with the job title of Jolly Good Fellow, ${ }^{348}$ a trade book by the director of the stress reduction clinic at the University of Massachusetts Medical Center about mindfulness for patients and physicians, ${ }^{349}$ a trade book by a neuroscientist about how practicing mindfulness can help overcome addictions, ${ }^{350}$ a trade book coauthored by neuroscientist/psychologist Richard Davidson and science journalist Daniel Goleman about how meditation produces enduring, long-term changes in human brains leading to happier, more compassionate and meaningful lives, ${ }^{351}$ and a trade book by Robert Wright, author of The Moral Animal, ${ }^{352}$ co-founder and editor-in-chief of Bloggingheads.tv, ${ }^{353}$ and editor-in-chief of MeaningOfLife.tv, ${ }^{354}$ about how modern evolutionary psychology and cognitive neuroscience provide scientific validation that practicing mindfulness meditation can lead to seeing reality clearer and achieving a deep, morally valid happiness. ${ }^{355}$

Many teachers have introduced mindfulness in their classes to improve the attention and emotional regulation of their students. ${ }^{356}$ There is evidence that practicing mindfulness benefits students, teachers, and parents. ${ }^{357} \mathrm{~A}$ free 45 -minute film, Healthy Habits of Mind, features neuroscientist and mindfulness researcher Richard Davidson, ${ }^{358}$ provides information about the neurobiology and research underpinning mindfulness, and showcases the value of mindfulness in educating children. ${ }^{359} \mathrm{~A} 55$-minute PBS documentary, Room to Breathe, follows Megan Cowan for several months as she teaches mindfulness to youths in a San Francisco public middle school with the most disciplinary suspensions in its district. ${ }^{360}$ A recent book by Thich Nhat Hanh, a Vietnamese monk, poet, scholar, and human rights activist, and Katherine Weare, an expert on social and emotional learning

John Kabat-Zinn, Wherever You Go, There You Are: Mindfulness Meditation in EVERYDAY LIFE (2005).

348 Chade Meng-Tan, Search Inside Yourself: The Unexpected Path to Achieving Success, Happiness (and World Peace) (2014); Chade Meng-Tan, Joy on Demand: The Art of Discovering the Happiness Within (2017).

349 Saki Santorelli, Heal Thy Self: Lessons on Mindfulness in Medicine (2000).

350 Judson Brewer, The Craving Mind: From Cigarettes to Smartphones to Love Why We Get Hooked and How We Can Break Bad Habits (2017).

351 Daniel Goleman \& Richard J. Davidson, Altered Traits: Science Reveals How Meditation Changes Your Mind, Brain, and Body (2017).

352 Robert Wright, The Moral Animal: Why We Are, the Way We Are: The New SCience of Evolutionary Psychology (1995).

353 Bloggingheads.tv, https://bloggingheads.tv/.

354 MeaningOfLife.tv, http://meaningoflife.tv/.

355 Robert Wright, Why Buddhism is True: The Science and Philosophy of Meditation and Enlightenment (2017). See also Robert Wright, Buddhism and Modern Psychology, Coursera, https://www.coursera.org/learn/science-of-meditation.

356 Lauren Cassani Davis, When Mindfulness Meets the Classroom, the AtLantic, Aug. 31, 2015, https://www.theatlantic.com/education/archive/2015/08/mindfulness-educationschools-meditation/402469/,

357 Mindful Schools, Why Mindfulness is Needed in Education, http://www.mindfulschools. org/about-mindfulness/mindfulness-in-education/.

358 Richard J. Davidson Webpage, http://richardjdavidson.com/.

359 Mindful Schools, Healthy Habits of Mind, http://www.mindfulschools.org/resources/ healthy-habits-of-mind/.

360 Mindful Schools, Multimedia, http://www.mindfulschools.org/resources/exploremindful-resources/\#just-breathe/. 
and mental health in schools, provides evidence-based guidance, practices, and techniques for teachers, administrators, counselors, and others to teach themselves and their students about mindfulness. ${ }^{361}$

A white paper by a senior faculty member of the center for creative leadership explains how practicing mindfulness helps develop enduring resilience by eliminating stress and its root cause, namely rumination. ${ }^{362}$ An engaging video introduction to practicing mindfulness is the PBS documentary, Mindfulness Goes Mainstream, which features singer and songwriter Jewel, psychologists and neuroscientists who have conducted research about mindfulness, and several authors of trade books about mindfulness. ${ }^{363}$ This general interest program consists of sections that explain how practicing mindfulness has been empirically found to have beneficial impacts on: (1) anxiety, stress, and depression; (2) pain and craving; and (3) focus and performance.

Law professor Debra Austin proposes the new field of positive legal education, that draws on the fields of positive psychology, neuroscience, and positive education. ${ }^{364}$ Austin "explains neuroscience research on habit learning, knowledge acquisition, and the impact of stress on cognition," 365 "illustrates how law student knowledge-base, legal skill acquisition, and professional identity development can be enhanced with discipline-specific growth mindset and self-efficacy training," 366 and "covers four practices lawyers can undertake to deal with the harmful effects of stress." ${ }^{\prime 367}$ Austin also has written articles that discuss how and why to engage in such restorative practices as gratitude, meditation, mindfulness, and yoga; ${ }^{368}$ the impact of such substances as Adderall, alcohol, caffeine, cocaine, marijuana, nicotine, opiates, and Ritalin on cognitive function; ${ }^{369}$ the connection between cognitive well-being and good nutrition; ${ }^{370}$ and mindfulness meditation, which is an empirically-supported strategy for emotional regulation, which is an essential skill of emotional intelligence. ${ }^{371}$

361 Thich Nhat Hanh \& Katherine Weare, Happy Teachers Change the World: A Guide for Cultivating Mindfulness in Education (2017).

362 Nick Petrie, Wake Up! The Surprising Truth about What Drives Stress and How Leaders Build Resilience, Aug. 2013, http://www.nicholaspetrie.com/wp-content/ uploads/2013/08/Wake-Up-The-Surprising-Truth-About-What-Drives-Stress-andHow-Leaders-Build-Resilience.pdf. See also generally Derek Roger \& Nick Petrie, Work without Stress: Building a Resilient Mindset for Lasting Success (2016).

363 Mindfulness Goes Mainstream (PBS broadcast Aug. 2017), http://pressroom.pbs.org/ Programs/m/MindFulness-Goes-Mainstream.

364 Debra S. Austin, Positive Legal Education: Flourishing Law Students and Thriving Law Schools, 77 Md. L. Rev. 649 (2018).

365 Id. at section III.

366 Id. at section VI.

367 Id. at section VIII.

368 Debra S. Austin, Killing Them Softly: Neuroscience Reveals How Brain Cells Die from Law School Stress and How Neural Self-Hacking Can Optimize Cognitive Performance, 59 Loy. L. Rev. 791 (2013).

369 Debra S. Austin, Drink Like a Lawyer: The Neuroscience of Substance Use and Its Impact on Cognitive Wellness, 15 Nev. L.J. 826 (2015).

370 Debra S. Austin, Food for Thought: The Neuroscience of Nutrition to Fuel Cognitive Performance, 95 Or. L. Rev. 425 (2017).

371 Debra S. Austin \& Rob Durr, Emotion Regulation for Lawyers: A Mind is a Challenging Thing to Tame, 16 Wyo. L. Rev. 387 (2016). 
Stanford law professor and clinical psychologist Joe Bankman posted an unpublished paper, ${ }^{372}$ that describes in detail a two-hour course he, Barbara Fried, and Ian Ayres developed and taught first-year law students at Stanford and Yale..$^{373}$ Any law professor or law school administrator can utilize the empirically validated cognitive reframing techniques in Bankman's paper to teach their law students about how to reduce anxiety, depression, and stress. The basis of Bankman's approach is Cognitive Behavioral Therapy (CBT) and what he calls The Cognitive Model, which

posits that emotions, physical sensations, and behaviors are influenced by automatic thoughts, assumptions, interpretations, and beliefs about self, others, and the world. The Cognitive Model assumes that people can learn to: 1) notice and identify negative automatic thoughts; 2) question automatic thoughts for accuracy or utility; 3) identify inaccuracy, exaggeration, or error (also referred to as cognitive distortions or unhelpful thoughts); and 4) challenge cognitive distortions and reframe automatic thoughts to interrupt the cycle and change emotions, physical sensations, and behaviors. ${ }^{374}$

Bankman also posted a one-page handout providing examples of unhelpful thinking styles or cognitive distortions, such as all-or-nothing thinking, catastrophizing, disqualifying the positive, jumping to conclusions, labelling, personalization, and overgeneralizing. ${ }^{375}$

Curious readers may wonder if mindfulness or CBT is more effective in managing anxiety, chromic stress, and depression. Robert Meikyo Rosenbaum, a neuropsychologist and psychotherapist, cogently discusses how neuroscience and psychology research about the efficacy of practicing mindfulness compared to alternatives (such as cognitive behavioral therapy, medication, and relaxation) distracts us and misses far more crucial issues (such as motivation to practice mindfulness, socioeconomic status, and the relationship between a mindfulness student and a mindfulness teacher). ${ }^{376}$ Popular media coverage often reports on brain imaging studies by "cognitive paparazzi" depicting colorful photographs of human brains during meditation in an fMRI machine. In fact, anything that humans do changes their brains, such as closing their eyes, practicing the piano, laying bricks, ${ }^{377}$ or being exposed for a single twenty-minute session in a tanning salon to ultraviolet rays. ${ }^{378}$

372 Joseph Bankman, Pyschoeducation about Anxiety - for You and Your Students, https:// www.colorado.edu/law/sites/default/files/Bankman\%20-\%20Materials\%20for\%20 Anxiety\%20Psychoeducation\%20Course.pdf.

373 Randee Fenner, Stanford Law Professor Creates New Way to Help Students Deal with the Stress of It All, STANFORD News, Apr. 7, 2015, http://news.stanford.edu/2015/04/07/ bankman-law-anxiety-040715/.

374 Id. at 6.

375 Unhelpful Thinking Styles, http://www.icctc.org/August2013/PMM\%20Handouts/ Unhelpful_Thinking_Styles.pdf.

376 Robert Rosenbaum, Mindfulness Myths: Fantasies and Facts, in What's Wrong WITH Mindfulness (and What Isn't): Zen Perspectives 53, 63-68 (Barry Magid \& Robert Rosenbaum eds., 2016).

377 Id. at 376 , at 55-56.

378 Id., at 59 n.6. See also Cynthia R. Harrington et al., Activation of the Mesotriatal Reward Pathway with Exposure to Ultraviolet Radiation (UVR) vs. Sham UVR in Frequent Tanners: A Pilot Study, 17 Addiction Biology 680 (2012). 
The website, Lawyers with Depression, helps law students, lawyers, and judges cope with and heal from depression. ${ }^{379}$ The thirty-minute documentary, $A$ Terrible Melancholy: Depression in the Legal Profession, features four lawyers and a former judge discussing personal experiences with depression, and several national experts about depression. ${ }^{380}$ The documentary's title is based on a book about Abraham Lincoln's life-long suffering from depression. ${ }^{381}$ A free book about depression and anxiety among law students and lawyers outlines the causes of anxiety, burnout, depression, and stress among law students and lawyers. ${ }^{382}$ The book also offers a guide to books about anxiety, depression, stress, and lawyer wellness in addition to related and online resources. ${ }^{383}$ A recent intriguing study ${ }^{384}$ "found visual cues within Instagram posts can help determine whether a user is suffering from depression." ${ }^{385}$ Recent research suggests that major depressive disorder, which is the world's leading source of disability, may be an evolved response to adversity instead of a discrete, specific, and unitary disease. ${ }^{386}$

\section{B. MY EXPERIENCES IN TEACHING HAPPINESS AND MINDFULNESS TO LAW STUDENTS}

I have taught law students about happiness and mindfulness in these courses (in alphabetical order): economic analysis of law; financial decision-making; law and human behavior; law, happiness, and neuroscience; law, happiness, and subjective well-being; legal ethics and professionalism: business law issues; media, law, and popular culture; neuroscience and law, and torts. In many of these courses, I have assigned as required readings: an eight-page article about whether lawyers can learn to be happy, written by Ted David, who is a tax law professor, tax practitioner, former Internal Revenue Service (IRS) agent, and IRS District Counsel attorney; ${ }^{387}$ a seven-page follow-up article about generators of happiness by the same author; ${ }^{388}$ a brief article from The Atlantic about meaning versus happiness; ${ }^{389}$ a twenty-

379 Lawyers with Depression, http://www.lawyerswithdepression.com/.

380 Bar Association of Erie County, A Terrible Melancholy: Depression in the Legal Profession, Vimeo, https://vimeo.com/14303016.

381 Joshua Wolf Shenk, Lincoln's Melancholy: How Depression Challenged a President and Fueled His Greatness (2006).

382 Daniel T. Lukasik, Overcoming Stress, Burnout, Anxiety, and Depression in the Legal Profession: How a Lawyer Life Coach Can Help 3-28 (2017).

383 Id. at 35-41.

384 Andrew G. Reece \& Christopher M. Danforth, Instagram Photos Reveal Predictive Markers of Depression, 6 EPJ DATA ScI. (2017).

385 Brett Molina, Can Your Instagram Photos Reveal If You're Depressed? USA TodaY, Aug. 10, 2017, 11:26 a.m. ET, https:/www.usatoday.com/story/tech/talkingtech/2017/08/10/ can-your-instagram-photos-reveal-if-youre-depressed/555210001/.

386 Vladimir Maletic \& Charles Raison, The New Mind-Body Science of Depression (2017).

387 Ted David, Can Lawyers Learn to be Happy? The Practical Lawyer, Aug. 2011, at 29.

388 Ted David, The Happiness Generators, The Practical Lawyer, June 2016, at 46.

389 Emily Esfahani Smith, There's More to Life Than Being Happy, The AtLantic, Jan. 9, 2013, https://www.theatlantic.com/health/archive/2013/01/theres-more-to-life-thanbeing-happy/266805/. 
page set of materials about boosting wellness, ${ }^{390}$ which includes many related books, TED talks, and web resources; and a nineteen-page trade book chapter about popular culture conceptions of happiness and unhappiness, ${ }^{391}$ that discusses key characters from House, ${ }^{392}$ a critically acclaimed, dramatic, fictional, popular medical television series whose titular character is a quirky, misanthropic genius addicted to pain medication and leader of a diagnostic team at Princeton-Plainsboro Teaching Hospital in New Jersey. I also have assigned a trade book, ${ }^{393}$ by Caroline Webb, who is a former McKinsey partner, that applies insights from behavioral economics, (positive) psychology, and neuroscience to provide readers step-by-step guidance about handling everyday work routines and tasks. ${ }^{394}$ The book explains how to set better priorities, make time go further, make the most of interactions, be the smartest, wisest, and most creative self, maximize personal impact, be resilient to annoyance and setbacks, and boost energy, enjoyment, and enthusiasm. ${ }^{395}$

I have learned many lessons from teaching law students about happiness and mindfulness, including these. First, it is important to explain that while one component of happiness is positive affect or emotion in the sense of feeling yippy-skippy, there are many other dimensions of happiness including the more cognitive notions of life satisfaction, meaning, and purpose. Second, regardless of the conception of happiness or subjective well-being being utilized, different people and societies may disagree over whether and how to trade off happiness with other desired goals. Third, empirical findings about the causes, correlates, and consequences of happiness and unhappiness usually arise from large crosssectional studies, meaning that your mileage may vary. Fourth, correlation is not causation. Fifth, longitudinal studies are rarer than cross-sectional studies because of the much higher costs in time and money involved to conduct multi-year studies. Sixth, mindfulness is a concept with which students are familiar with in the sense that they have to have been mindful to have gotten to where they are now. Seventh, the concept of mindfulness is not binary, zero or one; mindfulness has degrees along a continuum or spectrum. Eighth, students find it hard to believe that psychological and neuroscience research demonstrates that multi-tasking is an illusion and is really serial single-tasking with high switching costs. Ninth, there are people who believe the benefits that unhappiness and mindlessness always outweigh their costs. Tenth, being mindlessly mindful is still a form of mindlessness. Eleventh, people who learn about and study happiness and mindfulness can still be at times unhappy and mindless. Twelfth, happiness and mindfulness are skills that can be taught, learned, and improved through continual and regular practice. Thirteenth, happiness and mindfulness are habits and mindsets that can be acquired and maintained. Fourteenth, annoyances and frustrations offer opportunities to practice

390 Anne Brafford, Sandra Adkins, \& Jill Sanford, Wellness Booster Kit (2014).

391 Nancy L. Sim, Katherine M. Jacobs, \& Sonja Lyubomirsky, House and Happiness A

Differential Diagnosis, in House and Psychology: Humanity Is Overrated 77-94

(Ted Cascio \& Leonard L. Martin eds., 2011).

392 House (Fox television broadcast 2004-12).

393 Caroline Webb, How to Have a Good Day: Harness the Power of Behavioral Science to Transform Your Working Life (2016).

394 Caroline Webb, How to Have a Good Day Website, http://carolinewebb.co/books/howto-have-a-good-day/.

395 Id. 
happiness and mindfulness. Finally, it is important for law students, law professors, and lawyers to experience mindfulness directly, first-hand, and for themselves, preferably in-class, as soon as possible in discussing mindfulness through such three-minute guided meditations as these: the Body Scan Meditation ${ }^{396}$ and the Body and Sound Meditation. ${ }^{397}$ All of these are from a free set of guided meditations, ${ }^{398}$ the UCLA Mindfulness Awareness Research Center offers on its website. ${ }^{399}$

I candidly and openly share with law students about how practicing mindfulness has helped me overcome professional and personal fears, setbacks, and struggles. I disclose to law students how I and many people I know experienced anxiety, depression, and chronic stress in law school and law practice. I make these disclosures to reassure law students that having feelings of anxiousness, sadness, and being overwhelmed are okay. I remind them how as law students and lawyers, we can be overly critical of ourselves and engage in unhelpful rumination. I tell them that a blind date once told me that I think too much. I asked her how much should I think and agreed that overthinking is an occupational hazard about which I have to be mindful.

\section{CONCLUSIONS}

This Article discussed my adventures in higher education, happiness, and mindfulness. Although my unique adventures in higher education are atypical, hopefully they are still valuable for others to hear about because they may make you laugh and they involve situations that everyone can identify with and from which learn something. If nothing else, my unique experiences show how being so-called academically gifted or precocious is no guarantee to achieving happiness or practicing mindfulness.

After making a presentation at a conference, I accidentally dropped a laptop and its trackpad stopped working. I made an appointment at the nearest Apple store, where a technician fixed the laptop trackpad free of charge. Feeling in a good mood, I decided to visit a Tesla store in the same mall as the Apple store and ended up test driving a Tesla model S and model X on a nearby freeway. During one test drive, a Tesla employee engaged the enhanced autopilot feature, which combines cameras, GPS, radar, onboard computer, real-time information processing, and ultrasound sensors. I sat in the driver seat and watched in awe and amazement as the car steered itself, matched its speed to varying traffic conditions, stayed within a lane as that lane curved, and even changed lanes automatically, all without any driver input required. ${ }^{400}$ I excitedly told someone afterwards that I had just witnessed and experienced the future. She very wisely and gently reminded me that while that might be, we still live in the present. She reminded me that in the present, the

396 UCLA Health Website, UCLA Mindful Awareness Research Center, Body Scan Meditation, http://marc.ucla.edu/mpeg/Body-Scan-Meditation.mp3.

397 UCLA Health Website, UCLA Mindful Awareness Research Center, Body and Sound Meditation, http://marc.ucla.edu/mpeg/Body-Sound-Meditation.mp3.

398 UCLA Health Website, UCLA Mindful Awareness Research Center, Free Guided Meditations, http://marc.ucla.edu/body.cfm?id=22.

399 UCLA Health Website, UCLA Mindful Awareness Research Center, http://marc.ucla. $\mathrm{edu} /$.

400 Tesla, Autopilot, https://www.tesla.com/autopilot. 
infrastructure of rapid charging stations is not yet well developed as it most likely will be in the future. I was able to benefit from her mindfulness because it helped me to not buy a Tesla by outlasting my temporary fevered excitement from test driving a new technology.

A well-known behavioral legal scholar once told me that he thought it was ironic that while he was a Ph.D. student in psychology, he went out with someone who is now a leader in positive psychology and that person was quite unhappy then. My reaction was that many people choose to or end up studying happiness because they were quite unhappy in some period of their lives. Similarly, many people choose to or end up studying mindfulness because they were quite mindless in some period of their lives. If happiness and/or mindfulness came more naturally to these people, they would probably be less likely to choose to or end up studying happiness and/or mindfulness. That is certainly the case with me.

My niece $\mathrm{K}$ once asked me to play with her and I told her that I would in a few minutes after I finished up a train of thought I was working on in a paper I was writing. She incredulously and suspiciously asked why did I as a teacher still have to be writing papers instead of grading my students' papers? I told her that I was happy to write this paper. She asked me why. I told her because it was about happiness and writing it gave me the opportunity to study and learn about happiness. She then said "Uncle Peter, shouldn't everyone be studying and learning about happiness?" I said yes, everyone should and it is a shame and sad that is not already the case because a lot of people are unhappy and are not sure how to be happy. In the penultimate scene of the movie, Ingrid Goes West, the titular character is desperately unhappy and films a video of herself confessing her being at wit's end about how to change and be happy before overdosing on prescription medication. ${ }^{401}$ Everyone also can and should be studying and learning about mindfulness because a lot of people are mindless and are not sure how to be mindful.

I believe that teaching law students about happiness and mindfulness can help them professionally and personally. My belief is based on seeing this happen, student feedback in person, on teaching evaluations, in heartfelt "thank you" cards, and grateful emails from former law students, sometimes years after they graduated. If law students acquire a taste for learning about happiness and mindfulness, then they may continue to learn about and practice happiness and mindfulness for the rest of their lives. Happy and mindful law professors can teach and inspire law students to be happy and mindful, who in turn grow into and become happy and mindful lawyers, who may help their clients be happy and mindful, who in turn may help their communities and societies be happy and mindful. What a wonderful world that would be to help create and in which to live, flourish, and thrive.

$401 \quad$ INGRID Goes West (Neon 2017). 